NBER WORKING PAPER SERIES

\title{
EMPLOYEE COSTS OF CORPORATE BANKRUPTCY
}

\author{
John R. Graham \\ Hyunseob Kim \\ $\mathrm{Si} \mathrm{Li}$ \\ Jiaping Qiu \\ Working Paper 25922 \\ http://www.nber.org/papers/w25922 \\ NATIONAL BUREAU OF ECONOMIC RESEARCH \\ 1050 Massachusetts Avenue \\ Cambridge, MA 02138 \\ June 2019
}

We thank John Abowd, Ashwini Agrawal, Jonathan Berk, Rob Fairlie, Todd Gormley, Michael Hertzel, Joseph Hotz, Po-Hsuan Hsu, Robert Jarrow, Yawen Jiao, Pab Jotikasthira, Andrew Karolyi, Bryant Kim, Pauline Leung, Chen Lin, David Matsa, Roni Michaely, William Mullins, Paige Ouimet, Wendy Rotenberg, Ken Singleton, Yongjun Tang, Karin Thorburn, Michael Waldman, Wei Wang, Liu Yang, Hayong Yun, and seminar and conference participants at AFA, Census Bureau RDC Conference, Chicago Fed, Chinese University of Hong Kong, CICF, City University of Hong Kong, Cornell University (Finance and Labor Economics), CSEF-EIEF-SITE Conference on Finance and Labor, EFA, FIRS Conference, FMA Asia, IDC, Maryland Junior Corporate Finance Conference, NFA, SFS Finance Cavalcade, SOLE/EALE, University of Calgary, University of Hong Kong, and U.S. Census Bureau (CES) for helpful feedback. We also thank Bert Grider at the TFSRDC for help with data and clearance requests, Nichole Szembrot at the NYFSRDC (Cornell) for administrative support, and Dawoon Kim, Eric Kim, and Cindy Lu for research assistance. Any opinions and conclusions expressed herein are those of the author and do not necessarily represent the views of the U.S. Census Bureau. All results have been reviewed to ensure that no confidential information is disclosed. This research uses data from the Census Bureau's Longitudinal Employer Household Dynamics Program, which was partially supported by the following National Science Foundation Grants SES-9978093, SES-0339191 and ITR-0427889; National Institute on Aging Grant AG018854; and grants from the Alfred P. Sloan Foundation. We are grateful to Lynn LoPucki at UCLA for sharing his Bankruptcy Research Database and Edward Altman at NYU for sharing his dataset of default events. Kim acknowledges generous financial support from the Kwanjeong Educational Foundation. Li and Qiu acknowledge financial support from the Social Sciences and Humanities Research Council of Canada. This paper was previously circulated under the title "Human Capital Loss in Corporate Bankruptcy."

NBER working papers are circulated for discussion and comment purposes. They have not been peer-reviewed or been subject to the review by the NBER Board of Directors that accompanies official NBER publications.

(C) 2019 by John R. Graham, Hyunseob Kim, Si Li, and Jiaping Qiu. All rights reserved. Short sections of text, not to exceed two paragraphs, may be quoted without explicit permission provided that full credit, including (C) notice, is given to the source. 
Employee Costs of Corporate Bankruptcy

John R. Graham, Hyunseob Kim, Si Li, and Jiaping Qiu

NBER Working Paper No. 25922

June 2019

JEL No. G32,G33,J21,J31,J61

\section{$\underline{\text { ABSTRACT }}$}

An employee's annual earnings fall by $10 \%$ the year her firm files for bankruptcy and fall by a cumulative present value of $67 \%$ over seven years. This effect is more pronounced in thin labor markets and among small firms that are ultimately liquidated. Compensating wage differentials for this "bankruptcy risk" are approximately $2.3 \%$ of firm value for a firm whose credit rating falls from AA to BBB, about the same magnitude as debt tax benefits. Thus, wage premia for expected costs of bankruptcy are of sufficient magnitude to be an important consideration in corporate capital structure decisions.

John R. Graham

Duke University

Fuqua School of Business

100 Fuqua Drive

Durham, NC 27708-0120

and NBER

john.graham@duke.edu

Hyunseob Kim

Cornell University

Johnson Graduate School of Management

321 Sage Hall

114 East Avenue

Ithaca, NY 14853

hk722@cornell.edu

\section{$\mathrm{Si} \mathrm{Li}$}

School of Business and Economics

Wilfrid Laurier University

Waterloo, ON

N2L 3C5, Canada

sli@wlu.ca

Jiaping Qiu

DeGroote School of Business

McMaster University

Hamilton, ON

L8S 4M4, Canada

qiu@ mcmaster.ca 


\section{Introduction}

When a firm experiences a negative shock, its employees bear personal costs resulting from labor market adjustments. An extensive literature documents such costs to workers caused by plant closures, international trade, and environmental regulation, among other shocks (Jacobson, LaLonde, and Sullivan, 1993; Walker, 2013; Autor et al., 2014; Hummels et al., 2014). In this paper, we focus on costs to the workforce resulting from corporate bankruptcy and their implications for the firm's risk-sharing role and capital structure decisions.

According to the theory of the firm as an insurance provider, it is optimal for a risk-neutral firm to provide insurance to risk-averse workers (e.g., Baily, 1974; Azariadis, 1975). Workers are willing to accept lower wages in response, implicitly paying for this insurance (Guiso, Pistaferri, and Schivardi, 2005). When firms choose to use more debt financing (perhaps to achieve tax benefits), they increase bankruptcy risk, thereby reducing the risk-sharing benefit provided to employees (Berk, Stanton, and Zechner, 2010). Employees in response demand higher promised wages (Abowd and Ashenfelter, 1981). We estimate these compensating wage differentials, which can be thought of as an implicit bankruptcy-related cost of debt (Agrawal and Matsa, 2013). Most empirical estimates of the bankruptcy costs of debt seem small relative to the benefits (the "debt conservatism” puzzle; Graham, 2000). ${ }^{1}$ In this vein, our estimates help quantify a hard-to-measure indirect cost of bankruptcy, namely increased wages due to reduced risk sharing. We explore the extent to which wage premia could offset debt benefits as firms make capital structure choices.

We investigate these issues by estimating the impact of an employer's bankruptcy filing on its workers' earnings. Our analysis relies on worker-firm matched data from the U.S. Census Bureau's Longitudinal Employer-Household Dynamics (LEHD) program from 1985 to 2008,

\footnotetext{
${ }^{1}$ Traditional costs of financial distress or bankruptcy include those due to the bankruptcy process, such as lawyer's fees, loss of market share, and asset fire sales.
} 
combined with a comprehensive database of public firm bankruptcy filings. The LEHD data allow us to follow individual workers across firms over time and observe their wages and other characteristics of employment, such as industry and geographical location. As a result, we are able to estimate the effect of bankruptcy on employees, even when they change employers postbankruptcy.

We construct a sample of 140 bankruptcy filings by U.S. public firms from 1991 to 2005 and follow for up to six years approximately 277,000 workers who were employed by the bankrupt firms. We estimate the effect of bankruptcy filing on worker outcomes by comparing affected employees to workers in control firms matched to bankrupt firms using key firm characteristics before bankruptcy. In particular, using a propensity-score matching approach, we explicitly control for observable employer characteristics that are likely to be correlated with post-bankruptcy worker earnings, such as the firm's industry and economic performance.

We find that on average, employee earnings begin to deteriorate in the year of bankruptcy, relative to those of the control group. By two years after bankruptcy, annual earnings are 14\% lower than pre-bankruptcy annual earnings. The present value (PV) of earnings losses from the year of bankruptcy to six years afterward is $67 \%$ of pre-bankruptcy annual earnings. Importantly, earnings losses are larger for workers who leave the industry, and who work for small firms or in thin local labor markets, suggesting that labor mobility is an important determinant of labor market adjustments after corporate bankruptcy.

In competitive labor markets, employees would consider expected earnings losses that follow corporate bankruptcy and demand a wage differential ex ante. We estimate this compensating wage differential using two approaches. First, we regress employee earnings on firm leverage along with firm- and worker-level control variables, using 2.7 million worker-year 
observations from the LEHD data. These regressions indicate that employees of highly levered firms are indeed paid higher wages outside financial distress, controlling for firm and worker characteristics, and time-varying industry and local labor market conditions. Second, we document similar magnitude effects in an alternative approach based on a valuation model with plausible assumptions (such as worker risk aversion). We find that the expected additional present value cost to compensate for bankruptcy-driven earnings loss risk is about 1.3\% (3.6\%) of firm value for a typical AA-rated (BBB-rated) firm, relative to a risk-free firm. This $2.3 \%$ incremental distress cost is substantial in that it amounts to $51 \%$ (70\%) of the tax benefits of corporate debt for an AArated (BBB-rated) firm estimated in previous research (e.g., Graham, 2000). These two approaches, despite relying on different assumptions and estimates, produce quantitatively similar magnitudes of annual wage premia for bankruptcy risk (see Table 9). Overall, our analysis suggests that the magnitude of bankruptcy effects on employees may help explain the debt conservatism puzzle.

Our paper is related to two strands of literature. The first literature examines the earnings losses of displaced workers. A central finding of this line of research is that job displacement (i.e., job loss resulting from mass layoffs) leads to large and persistent earnings losses (e.g., Jacobson, Lalonde, and Sullivan, 1993; von Wachter, Handwerker, and Hildreth, 2009; Couch and Placzek, 2010; von Wachter, Song, and Manchester, 2011). This literature also shows that the effect of job displacement on earnings is especially large when labor market conditions are weaker, such as in recessions (Schoeni and Dardia, 2003; Kodrzycki, 2007; Davis and von Wachter, 2011).

Our paper differs from the existing work on displaced workers in several important ways. First, we focus on one specific financial shock on workers, namely corporate bankruptcy, as opposed to pure job displacements. As we show later, the workers in our sample of bankrupt firms are not necessarily displaced, with a substantial fraction of them staying with the bankrupt 
employer. Thus, our estimates of earnings losses are based on bankrupt firm employees, whether or not they separate from or remain with the firm after bankruptcy. Second, importantly, it is not possible to directly infer the employee cost of bankruptcy from estimates in the displacement literature, which is important for drawing implications for the corporate cost of debt and capital structure. This is because i) given that not all employees leave the bankrupt firm, non-job separators may not be an appropriate control group for bankrupt firm employees, even though they are often used as the counterfactual earnings group in the job displacement literature; and ii) relative to workers who leave the firm, workers who stay with the bankrupt firm may have different earnings loss patterns associated with bankruptcy, which a displaced worker analysis would not capture. For example, we find that firm stayers of bankrupt firms lose about present value $72 \%$ of pre-bankruptcy annual earnings after bankruptcy relative to firm stayers of non-bankrupt firms. Third, in a step beyond what most of the job displacement literature does, we attempt to disentangle the effect of financial distress from economic distress on employee earnings.

The second strand related to our paper is the finance literature on the impact of financial distress on employees. Our paper is among the first to use worker-firm matched micro data to examine labor market outcomes for individuals after financial distress of the firm. ${ }^{2}$ While previous research has examined the effects of bankruptcy filings on firm-level outcomes such as accounting performance and management turnover (Gilson, 1989; LoPucki and Whitford, 1992), relatively little is known about the consequences of bankruptcy and financial distress for employees, other than firm-level employment. ${ }^{3}$ Our paper estimates detailed changes in employee earnings upon

\footnotetext{
${ }^{2}$ A contemporaneous paper by Baghai, Silva, Thell, and Vig (2018) uses Swedish employer-employee matched data to document that financially distressed firms lose their most skilled employees. However, they do not examine changes in employee wages around financial distress nor wage premia for financial distress risk, which are our focus.

${ }^{3}$ For instance, using Compustat data on firm-level employment, Falato and Liang (2016) show that firms cut employment substantially after loan covenant violations, and Agrawal and Matsa (2013) show that firms reduce employment by about 30\% during the years surrounding bond defaults. Similarly, Hotchkiss (1995) shows that firms suffer employment reductions around Chapter 11 bankruptcy filings.
} 
bankruptcy relative to a control group using worker-level data. To the extent that quantifying the magnitude of employee earnings losses associated with default or bankruptcy is important (e.g., for estimating expected costs of financial distress; see the next paragraph and Matsa (2018)), our approach quantifies figures important to this line of research, namely the present value of earnings losses associated with corporate bankruptcy filings.

We derive wage premia for bankruptcy risk as labor-related indirect bankruptcy costs. Capital structure theories model that employee wage loss due to financial distress discourages firms from using debt (e.g., Titman, 1984; Butt-Jaggia and Thakor, 1994; Berk, Stanton, and Zechner, 2010). Agrawal and Matsa (2013) and Kim (2018) provide evidence of the importance of this mechanism by showing that changes in the cost of job loss affect corporate capital structure decisions. In our paper, we not only show evidence for the importance of this mechanism, but we also quantify the magnitude of these wage premia for employees' earnings loss risk due to bankruptcy. Differing from existing estimates of wage premia based on firm-level aggregate wage data (Chemmanur, Cheng, and Zhang, 2013) or implied by compensating differentials for unemployment risk (Agrawal and Matsa, 2013), we use worker-level wage data from LEHD to directly estimate the wage premia. Our analysis suggests that the resulting additional compensation cost is of similar magnitude to the tax benefit of debt and thus could play a first-order role in corporate capital structure decisions. The wage premia are particularly large when workers face limited mobility (e.g., employed by small firms, in smaller local labor markets).

\section{Data and Descriptive Statistics}

\subsection{Data Sources and Sample Selection}

\subsubsection{Bankruptcy Event Data and LEHD Datasets}


We begin by identifying corporate bankruptcy cases from the UCLA-LoPucki Bankruptcy Research Database (BRD). ${ }^{4}$ The BRD contains public companies with more than $\$ 100$ million of assets (measured in 1980 dollars) that filed bankruptcy cases from October 1, 1979 to present. $^{5}$ We focus on public firms' bankruptcy filings because we examine capital structure implications later in the paper. ${ }^{6}$

We merge these bankruptcy events to worker-firm matched information from the U.S. Census Bureau's Longitudinal Employer-Household Dynamics (LEHD) program, establishmentlevel databases, and the Compustat database. The LEHD data we have access to cover 30 participating U.S. states (see Table 1 for the list of covered states) and provide detailed information on employment relationships such as employee earnings, industries, and geographical locations and worker characteristics such as age, education, and gender. ${ }^{7}$ The annual wage records in LEHD are non-missing as long as an individual reports positive earnings in any of the four quarters in the year. However, if the individual earns nothing in any quarter of the year, the annual record is missing (as opposed to showing zero earnings). Thus, missing observations are due to two potential reasons. First, an individual may move to any of the 20 non-LEHD states or become self-employed (in which case no earnings are reported in the LEHD data based on state UI records). Second, the

\footnotetext{
${ }^{4}$ We thank Lynn M. LoPucki at UCLA for sharing this database, which is also used by Jiang, Li, and Wang (2012), Eckbo, Thorburn, and Wang (2016), and Goyal and Wang (2017).

${ }^{5}$ The majority of bankruptcy cases in the database are filed under Chapter 11 (reorganization) of the U.S. Bankruptcy Code, while only a handful are filed under Chapter 7 (liquidation).

${ }^{6}$ Using a 235 private firm sample selected by BankruptcyData.com that have public debt or that BankruptcyData deemed important, we find that employees of these private bankrupt firms experience almost three times larger earnings losses after a bankruptcy filing than their public firm counterparts. Possible explanations include that public firms, which tend to be larger, offer better opportunities for employees to develop general skills or to switch jobs in general. The results are consistent with our findings that there is significant heterogeneity in employee costs of bankruptcy depending on firm size and search frictions in the labor market. See Bernstein, Colonnelli, and Iverson (2019) for a study of asset reallocation effects of bankruptcy using a large sample of bankruptcy filings by both public and private firms. They focus on the difference between reorganization and liquidation but do not study employee costs or capital structure implications of the bankruptcy processes.

${ }^{7}$ The Census Bureau imputes the education variable as follows. For each state, a logit model is used to estimate the probability of belonging to one of 13 education categories using the characteristics such as age categories, earnings categories, and industry indicators. The education category is then imputed based on the predicted probability.
} 
individual may become unemployed and earn no wages in a given year. We empirically address how these sample attrition issues affect our estimates in Section 3.1.

We link datasets from the LEHD infrastructure with other Census Bureau establishmentlevel datasets and subsequently with Compustat and BRD. Specifically, among the databases available from the LEHD infrastructure, we use the Individual Characteristics File (ICF), which provides worker-level characteristic variables; the Employment History File (EHF), which contains annual and quarterly earnings records, locations (state and county) and industries for each worker-firm pair; and the Unit-to-Worker Imputation File (U2W), which is used for job-location imputation at the SIC (or NAICS) industry and county level. We use the Business Register Bridge (BRB) and the Compustat-SSEL Bridge (CSB) in conjunction with the Standard Statistical Establishment List (SSEL) to link the LEHD files with the Census Bureau's Longitudinal Business Database (LBD), Compustat and the BRD. To avoid complications associated with legal ages for employment and early retirement, we require that worker ages be between 22 and 50 in the year before a bankruptcy filing (e.g., Davis and von Wachter, 2011). To exclude earnings changes due to unstable employment relations with the firm (e.g., temporary workers), we focus on workers with at least two years of tenure with the bankrupt firm one year before its bankruptcy filing. ${ }^{8}$

Because wages are a key variable in our analysis, we provide details on LEHD wage records below. As discussed in Abowd et al. (2009), the LEHD wage data are reported on a quarterly basis with historical time series extending back to the early 1990s for many states (see Table 1). The LEHD wages are extracted from the state unemployment insurance (UI) records and correspond to the report of an individual's UI-covered earnings, which is retained in the database as long as the worker earns at least one dollar of UI-covered earnings during a given quarter.

\footnotetext{
${ }^{8}$ Robustness tests requiring at least six years of tenure give similar results, which are available upon request.
} 
According to the Bureau of Labor Statistics (BLS), UI coverage is comprehensive and comparable across states. For example, UI covered $96 \%$ of total jobs and $92.5 \%$ of the wage component of national income in 1994. The UI earnings include gross wages and salaries, bonuses, stock options, tips and other gratuities, and the value of meals and lodging, where supplied. In some states, employer contributions to certain deferred compensation plans, such as $401(\mathrm{k}) \mathrm{s}$, are included in total earnings. ${ }^{9}$

[Table 1 about here]

\subsubsection{Census Establishment-Level Data}

We use the Longitudinal Business Database (LBD) to obtain comprehensive data on employment and wage bills at establishments owned by bankrupt firms. The LBD tracks more than five million establishments each year from 1977 to 2011 covering all U.S. states. The variables available in the database include the number of employees, annual payroll, industry classifications, location identifiers (e.g., states, counties), and parent firm identifiers. However, the LBD does not contain data on worker-level earnings, industries, or location of employment, which are contained in the LEHD.

\subsubsection{Sample Selection: Bankrupt and Matched Firms}

We begin with 510 bankruptcy cases from the BRD from 1990 to 2005 (excluding financials and utilities). We match these firms with Compustat and SSEL and require that they have non-missing financial information from Compustat. This step produces 360 bankruptcy cases. We then match these bankrupt firms with LEHD data and keep firms with at least ten employees in LEHD one year before filing. LEHD data begin its coverage in 1990 (the exception is Maryland, which begins coverage in 1985). The LEHD covers 30 states but excludes several large states in

\footnotetext{
${ }^{9}$ See https://www.bls.gov/opub/hom/cew/pdf/cew.pdf at the BLS.
} 
earlier years of the coverage (for example, New Jersey starts coverage in 1996). See Table 1 for a full list of the 30 states covered and years available. Because the LEHD earnings data we have access to are only available up to 2008, we include only the bankrupt firms that file for bankruptcy in or before 2005. This restriction allows employees of bankrupt firms in 2005 to have up to three years of earnings data post-bankruptcy.

To construct a matched sample from non-bankrupt firms, we first require that the nonbankrupt firms have non-missing matching variable information and have at least ten workers from LEHD one year before matching from 1990 to 2005. Then for each year and three-digit SIC industry, we use a propensity score matching approach in which we use book assets, return on assets (ROA), market-to-book, and total number of employees (from the LBD) to find matched non-bankrupt firms. More specifically, we obtain the financial information in the year prior to bankruptcy filings for bankrupt firms and the information for potential matches in the same year and industry. ${ }^{10}$ The propensity score matching is performed within each year-industry cell to control for the influences of unobserved time-varying aggregate and industry conditions. Note that we use ROA and market-to-book but not leverage in matching, which allows us to control for the impact of firm performance but allows bankrupt firms to have different leverage than matched firms.

For each bankrupt firm in the sample, we choose one non-bankrupt firm that has the closest linearized propensity score (LPS or log odds ratio) as a matched firm. We follow the matching literature and require that the absolute difference in the LPS be less than or equal to 0.25 (see e.g., Imbens and Rubin, 2015). If we do not find a matched firm within a given three-digit SIC-year cell based on the cut-off, we repeat the matching process to find a matched firm within a given

\footnotetext{
${ }^{10}$ When we conduct the matching based on four years prior to bankruptcy filings (which is our benchmark year in earnings regressions), we obtain similar results.
} 
two-digit SIC-year cell, and then within an one-digit SIC-year cell. This one-to-one matching procedure gives us a final event sample consisting of 140 bankrupt and 140 matched firms from 1991 to 2005 that employ at least ten workers one year before bankruptcy.

\subsection{Descriptive Statistics}

\subsubsection{Firm Characteristics of Bankrupt and Control Firms}

Table 2 presents descriptive statistics on bankruptcy events, firms and matched firms. Panel A shows that the distribution of bankrupt firms with employees in the LEHD data is similar to the full sample of bankrupt firms from the BRD, in terms of bankruptcy outcomes. Bankruptcy events that lead to acquisition, merger, or continuation of the firm represent about $43 \%$ of the events in both samples, and those leading to liquidation, firm closure, and refiling represent about 20\%. The first four columns of Panel B further investigate the representativeness of the bankrupt firms that have workers in LEHD based on firm characteristics measured in the latest fiscal year within two years before bankruptcy. The statistics show that bankrupt firms from BRD that have information from Compustat and SSEL and the bankrupt firms with employees in LEHD are similar in firm size, leverage, and market-to-book. Bankrupt firms in LEHD are more profitable and employ more workers (obtained from the LBD). This characterization is sensible given that firms with larger employment are more likely to have employees across states and thus are more likely to be matched with the LEHD data.

Importantly, Panel B compares bankrupt firms with employees in LEHD (columns (3) and (4)) to propensity-score matched firms (columns (5) and (6)) by examining the means and standard deviations of firm characteristics. ${ }^{11}$ The $t$-statistics reported in column (8) on the differences between the means show that the bankrupt firms with employees in LEHD and matched firms do

\footnotetext{
11 The Census Bureau does not permit researchers to disclose percentiles including the median.
} 
not differ significantly in the matching variables, including book assets, the number of employees, ROA, and market-to-book. The two groups also have similar sales and market value of assets, although these variables are not explicitly employed in matching. Notably, the bankrupt firms have significantly higher market leverage than matched firms (57\% vs. $30 \%$ ), which is consistent with leverage playing a role in "treated" firms ending up in bankruptcy. (Recall that the matching process intentionally does not match on leverage.)

[Table 2 about here]

Table 2, Panel C shows the dynamics of firm characteristics for bankrupt and matched firms starting three years before bankruptcy filings. To facilitate a balanced comparison of statistics across the years, we focus on a subset of bankrupt firms that have complete financial information from Compustat and LBD (on employment) during all the three years $\mathrm{t}-3$, $\mathrm{t}-2$, and $\mathrm{t}-$ 1. This requirement leaves us with 120 bankrupt firms and their corresponding control firms. Over the years, sales, book assets, and number of employees do not exhibit significant changes. Market value of assets for bankrupt firms declines over the years, but the difference between the treatment and control groups for each year is not statistically significant. Both groups also show a similar declining trend in profitability and the market-to-book ratio over time, with the values across the two groups being statistically indistinguishable. Notably, bankrupt firms exhibit substantially higher levels and changes in leverage than matched firms for each year before bankruptcy, although the matched group also experiences a modest increase in leverage over the years.

Overall, the results in Table 2 confirm that bankrupt and matched firms are similar in firm size, growth opportunities, profitability, and their trends prior to the event year, suggesting that the matched firms are a valid control sample for our analysis.

\subsubsection{Employee Characteristics of Bankrupt and Control Firms}


Table 3 presents employee characteristics from LEHD for the bankrupt and control firms. We examine employees of these firms one year prior to the bankruptcy filing. The worker characteristics, including education, age, experience, gender, and earnings, are similar between the employees of bankrupt and the propensity-score matched control firms. All of the $t$-statistics for testing the difference are insignificant at conventional levels (column (7)). In addition to comparing with the propensity-score matched sample, we follow the literature on labor market adjustments to job displacements (e.g., Couch and Placzek, 2010; Davis and von Wachter, 2011) and construct an alternative, less strict control sample of employees. To circumvent computational constraints, we randomly select $1 \%$ of workers in the LEHD universe (which contains more than 2.8 billion quarterly earnings records) who are (i) employed by non-bankrupt public firms and (ii) not displaced from an employer due to plant closure. We impose the same requirements on the control group for industry (i.e., exclude financial and utilities sectors), tenure, and age as we impose on the sample of bankrupt firms. Column (8) shows that while the years of experience are statistically different, other characteristics are similar between the bankruptcy and the randomly selected workers. Overall, the comparisons of employee characteristics suggest that the propensityscore matched group of workers is more comparable to the treatment group.

The data in the bottom half of Table 3 documents the rate at which employees move across firms, industries, and counties of employment around bankruptcy filings. We first report the fraction of workers who are employed by the firm in year t-4 and stay in the same firm, industry, or county through $\mathrm{t}-1$, separately for treated and matched firms. The results show that before bankruptcy, the treated and matched control groups are comparable in terms of employees moving. In particular, the rates of staying in the same firm, industry, and county from t- 4 to t- 1 are $51.5 \%$ 
vs. $50.1 \%, 72.8 \%$ vs. $67.4 \%$, and $71.1 \%$ vs. $64.1 \%$, respectively, for bankrupt versus matched firms, with all pairs not being statistically different from each other (column (7)).

When tracking the employees from one year prior until three years after bankruptcy, however, we find a considerable decline in the rates that employees of the bankrupt firms remain in their original firm, industry, and county, relative to employees of the control firms. Only $37.2 \%$ of employees stay in their bankrupt firm (vs. $47.5 \%$ in the control firm), $54.4 \%$ stay in their industry of employment (vs. 64.6\%), and 56\% stay in the county in which they work prebankruptcy (vs. 66.1\%). The $t$-statistics for the differences in industry and county attrition rates from $t-1$ to $t+3$ versus from $t-4$ to $t-1$ between the two groups are significant at the $5 \%$ level (see the last two rows of column (7)).

In summary, Table 3 shows that the employees of the bankrupt firms are comparable to those of the matched firms along key individual characteristics observed before bankruptcy. However, it shows that employees of bankrupt firms are more likely to leave the industry and local area post-bankruptcy, relative to years prior to bankruptcy. This change-in-the-propensity-ofleaving pattern does not hold for employees of non-bankrupt firms.

[Table 3 about here]

\section{Empirical Results}

\subsection{Effect of Corporate Bankruptcy on Employee Earnings}

We employ a difference-in-difference approach to estimate earnings changes for employees of bankrupt firms relative to earnings changes that would have occurred in the absence of bankruptcy, controlling for various fixed effects and individual characteristics. Specifically, we estimate the following regression equation:

$y_{i t}=\alpha_{i}+\gamma_{j t}+\mu_{c t}+\beta x_{i t}+\sum_{k=-3}^{6} \lambda_{k} d[k]_{i t}+\sum_{k=-3}^{6} \delta_{k} d[k]_{i t} \times B R_{i}+\varepsilon_{i t}$, 
where $i, j, c$, and $t$ index workers, industries, counties, and years, and $y_{i t}$ is worker $i$ 's logarithm of real annual earnings (adjusted using the CPI in 2001 constant dollars) in year $t$. For a worker who holds multiple jobs (i.e., several worker-firm matches) in a given year, we use the worker's total earnings aggregated across all her jobs in that year. $\alpha_{i}, \gamma_{j t}, \mu_{c t}$ represent worker, industry $\times$ year, and county $\times$ year fixed effects. $x_{i t}$ includes the following time-varying worker characteristics: years of experience (defined as age - education -6 ), years of experience $\times$ years of education, and years of experience $\times$ female indicator. We do not include education or a female indicator as standalone variables because they are constant at the individual level and thus are collinear with worker fixed effects. We do not include age because it is collinear with experience and education. $d[k]_{i t}$ is an indicator variable equal to one if year $t$ is $|\mathrm{k}|$ years before or after a bankruptcy filing, and zero otherwise $(-3 \leq k \leq 6) . B R_{i}$ is an indicator variable equal to one if worker $i$ was an employee of a bankrupt firm one year prior to bankruptcy, and zero if the worker was an employee of a control firm. $\varepsilon_{i t}$ is the random error. Standard errors are clustered at the firm level.

We study employees that work at the bankrupt (or control) firms one year prior to the bankruptcy filing (or year of matching) and analyze these employees from $t-4$ to $t+6$ to estimate equation (1). Thus, the implicit benchmark is earnings in year t-4 for both groups, and the event indicator variables begin in t-3. The estimates of $\delta_{k}$ capture the change (from the benchmark year t-4) in earnings of bankrupt firms' employees in each event year relative to those of the control group. We include worker fixed effects to control for unobserved individual-level heterogeneity. We include two-digit SIC industry $\times$ year fixed effects to control for unobserved time-varying shocks specific to industries. County $\times$ year fixed effects control for time-varying economic shocks specific to local areas. 
Table 4 presents results for the dynamics of employee earnings around corporate bankruptcy filings. The control group includes employees of the propensity-score matched firms in Panel A, and randomly selected employees of non-bankrupt public firms who are not displaced in Panel B. The estimates on the interaction terms $d[k] \times B R(0 \leq k \leq 6)$, the variables of interest, show that relative to the control group, employees of bankrupt firms experience significant reductions in earnings over the years after a bankruptcy filing. Across all specifications, most of the coefficients on the interaction terms are significantly negative at conventional levels from $\mathrm{t}$ to $\mathrm{t}+5$.

\section{[Table 4 about here]}

We examine the economic magnitude of the employee earnings losses associated with bankruptcy filings using estimates in column (2) of Panel A, which includes worker and industry $\times$ year fixed effects. We use column (2) as the preferred specification to ensure that our estimates do not simply reflect time-varying industry conditions. In particular, controlling for effects of (industry-level) economic performance on earnings is important given our goal to show an empirical link between financial distress and employee earnings losses. For example, bankrupt firm employees may be in industries that have suffered negative economic shocks, which would affect their subsequent earnings even in the absence of bankruptcy filings. By including industry $\times$ year fixed effects, we control for earnings heterogeneity driven by these industry conditions.

In column (2), the -0.103 coefficient on $d[0] \times B R$, which is the difference between log earnings in year $\mathrm{t}$ and log earnings in benchmark years t-4 for bankrupt firms, relative to the same difference for matched control firms, implies a 9.8\% decline (= exp(-0.103) - 1) in earnings in year t relative to the counterfactual earnings. Similarly, the coefficients on $d[k] \times B R(1 \leq k \leq 6)$ indicate an average annual earnings loss of around $11 \%$ relative to the benchmark earnings and to the non- 
bankrupt firm employees. The last row in the panel shows that the present value (PV) of earnings losses during the seven years since bankruptcy filing, computed using a real discount rate of 5.48\%, is $67.1 \%$ of the pre-bankruptcy annual earnings (measured in benchmark year t-4). ${ }^{12}$

The other columns in Table 4 explore whether our results are robust with respect to econometric specifications with different fixed effects. All specifications control for worker fixed effects. In general, when we use less refined layers of fixed effects (e.g., year rather than industry $\times$ year), heterogeneity that we do not control for (such as industry-specific shocks mentioned above) may result in a larger (absolute) magnitude of earnings losses for bankrupt firm employees. In column (1), which includes year fixed effects, we find that the present value of earnings losses is 83.9\% of pre-bankruptcy earnings. Columns (3) through (5) include county $\times$ year, both industry $\times$ year and county $\times$ year, and industry $\times$ county $\times$ year fixed effects, respectively. These fixed effects control for time-varying shocks at the industry- and county-levels. Earnings losses in these specifications remain reasonably similar to (albeit smaller than) that in column (2). Overall, the estimated earnings losses are substantial, persistent up to five years after bankruptcy, and robust to specifications using different layers of fixed effects. In addition, despite some variation across specifications, our calculations based on column (2) appear to provide a reasonable characterization of employee earnings losses after bankruptcy.

We report the regression results based on the randomly selected control group of workers in Panel B of Table 4. The magnitudes of earnings loss estimates are generally larger when these workers are used as the control group. For example, column (2) of Panels A and B shows present

\footnotetext{
${ }^{12}$ To calculate the PV of earnings losses, we use a real (i.e., inflation-adjusted) discount rate that is appropriate for the risk of individual earnings, given that the earnings loss estimates are in real terms. Assuming that the risk of employee earnings is similar to that of corporate bonds, we use the average corporate BBB bond yield minus average inflation rate (i.e., CPI changes) from 1985 to 2008 (our sample period), which is 5.48\%. Sullivan and von Wachter (2009) and Davis and von Wachter (2011) use 4\% and 5\% as a real discount rate to compute the PV of earnings losses. The row shows $t$-statistics based on standard errors calculated using the delta method in parentheses.
} 
value earnings losses are $67 \%$ and $77 \%$ of the benchmark annual earnings, respectively. This result suggests that the latter estimates may be biased upward (in absolute value), likely due to lack of controls for firm-level characteristics, particularly economic performance proxies such as ROA and market-to-book.

Figure 1 visually presents the earnings dynamics based on the coefficient estimates in column (2) of Panel A. The figure shows that earnings of bankrupt firm employees (relative to those of propensity-score matched control firm employees) experience modest declines (2-4\%) from the benchmark year, $\mathrm{t}-4$, during the pre-bankruptcy period from $\mathrm{t}-3$ to $\mathrm{t}-1$. These declines however are not statistically different from zero. Earnings are significantly low in the year of the bankruptcy filing and remain low from that year onward. From $t$ to $t+6$, employees lose $11 \%$ of the pre-bankruptcy (t-4) annual earnings on average, relative to the earnings of the matched firm employees in the respective year.

[Figure 1 about here]

As mentioned in Section 2.1.1, missing earnings in the LEHD data could be due to an individual moving to a non-LEHD state, becoming self-employed, or becoming unemployed. To examine the implications of missing observations for earnings loss estimates, we provide additional estimates for the present value of earnings losses using two imputation approaches. ${ }^{13}$ First, for both treatment and control groups, we replace missing earnings with the $10^{\text {th }}$ percentile value of the earnings distribution in our sample. ${ }^{14}$ This approach essentially assumes that individuals who disappear from the LEHD data are (nearly) unemployed. Alternatively, we replace

\footnotetext{
${ }^{13}$ See e.g., Walker (2013), who uses similar imputation approaches to address limitations of the LEHD data.

${ }^{14}$ We also impute missing earnings with the $1^{\text {st }}$ and $5^{\text {th }}$ percentile values of the earnings distribution and obtain similar results. Imputing missing earnings with zero leads to many observations with zero earnings (more than a quarter of the imputed sample). This generates noisy estimates of PV earnings loss, particularly when layers of interacted fixed effects are included.
} 
missing annual earnings with four times the individual's last observed quarterly earnings in the LEHD data; this approach effectively assumes that the individuals who disappear move to work in non-LEHD states or become self-employed and earn the same wages as before. ${ }^{15}$ We note that the present value of earnings losses based on the first approach is not necessarily greater than the second approach because in either approach, we apply the imputation to the employees of both treatment and control firms and the present values are computed using a difference-in-difference estimate between the two groups. We report the estimates in Table 4, Panel C. Under both imputation approaches, the present values of earnings losses are similar in magnitude to those in our main regressions without imputations.

\subsection{Worker Reallocation as a Mechanism of Earnings Losses after Bankruptcy}

Our main analysis documents a significant decline in earnings for average employees of bankrupt firms. However, the baseline estimates could mask rich heterogeneity in their labor market adjustments post-bankruptcy. In this section, we condition our estimation of earnings dynamics on whether workers reallocate across firms, industries, and geographical areas postbankruptcy, as well as on labor market characteristics. In the process, we shed light on two mechanisms through which workers may suffer earnings loss: costs to worker mobility, and loss of firm- or industry-specific human capital. We consider the results in this section suggestive and thus interpret them with caution, given that worker selection on observable and unobservable characteristics (e.g., ability) is likely to affect both the conditioning variable (e.g., whether switching industries) and post-bankruptcy earnings. We partly mitigate this concern by including

\footnotetext{
${ }^{15}$ If a worker leaves an employer in an LEHD state for a non-LEHD state or to become unemployed in the middle of a year (say June), annual earnings in her previous job may underreport her "true" annual earnings in that job. To mitigate this limitation, we impute missing annual earnings using the last observed quarterly earnings multiplied by four (i.e., annualized). Imputing using the last observed annual earnings produces similar magnitude PV earnings losses.
} 
worker fixed effects in the empirical specification. In this and other sections throughout the rest of this paper, we use the specification that includes worker and two-digit SIC industry $\times$ year fixed effects (see column (2) of Table 4, Panel A, and related discussion in Section 3.1).

\subsubsection{Worker Movement and Post-Bankruptcy Earnings}

If an important part of earnings loss during labor market adjustments is due to the loss of human capital specific to firms (Becker, 1962) or industries (Neal, 1995), then the costs of bankruptcy might be largely borne by workers who leave their firms or industries. To test these predictions, in the following regression specification we employ an indicator variable Stay, which is equal to one if a worker stays in the same firm, the same two-digit SIC industry, or the same county through year $t+3$ :

$y_{i t}=\alpha_{i}+\gamma_{j t}+\beta x_{i t}+\sum_{k=-3}^{6} \lambda_{k} d[k]_{i t}+\sum_{k=-3}^{6} d[k]_{i t} \times B R_{i} \times\left(\delta_{k}\right.$ Stay $_{i}+\theta_{k}\left(1-\right.$ Stay $\left.\left._{i}\right)\right)+\varepsilon_{i t}$,

where the coefficients $\delta_{k}$ represent the effect of bankruptcy on earnings of the bankrupt firm employees who stay in the firm (or industry, or county), and the coefficients $\theta_{k}$ represent the effect on earnings of the bankrupt firm employees who do not stay. ${ }^{16}$ We stratify the treatment (i.e., bankruptcy) group based on whether workers stay with their firms (or industries, or counties) until $\mathrm{t}+3$. We do not stratify the control group, so our analysis decomposes earnings losses of the treated group relative to the average worker in the control group (see e.g., Walker (2013) for a similar stratification).

\section{[Table 5 about here]}

We first examine whether the magnitudes of earnings losses are different between the employees who stay with the bankrupt firm and those who leave the firm (Table 5, Panel A).

\footnotetext{
${ }^{16}$ Note that the specification in equation (2) does not include the stand-alone Stay indicator as it is collinear with worker fixed effects. Also, we find similar results if we alternatively define the Stay indicator equal to one if a worker stays in the same firm, two-digit SIC industry, or county through t+5.
} 
Comparing the estimates indicates that "firm leavers" (column (2)) generally fare worse than "firm stayers” (column (1)) during the years after the bankruptcy filing. For example, using the presentvalue approach described in Section 3.1, workers who leave the firm lose on average $86 \%$ of their annual earnings for the seven years from $\mathrm{t}$ to $\mathrm{t}+6$ (significant at the $1 \%$ level), while those who stay with the firm have a statistically insignificant gain of $25.6 \% .{ }^{17}$

We next unpack the earnings loss of the workers who leave the bankrupt firm along another dimension, conditioning on whether they leave the industry and/or county. If an employee's human capital (e.g., skill set) is specific to her original industry, the earnings loss would be more pronounced for "industry leavers," all else equal. Consistent with this prediction, columns (5) and (6) show that among county leavers, earnings losses for industry leavers are substantially more negative than for the industry stayers. (Columns (3) and (4) examine county stayers and also find a negative, though much smaller, industry leaver effect.) These results imply that the cost of corporate bankruptcy is borne by workers who leave their industries (but not by those who stay in the same industries even though leaving their original firms), consistent with industry-specific human capital playing an important role in labor market adjustments after bankruptcy. ${ }^{18}$ We note, however, that the association between switching industry and earnings losses could be due to

\footnotetext{
${ }^{17}$ Note that the above results show the earnings losses of stayers and leavers in the treated group relative to the average worker in the control group. Instead of using the average worker in the control group as the benchmark, we further examine whether stayers (leavers) of the bankrupt firm fare worse than the stayers (leavers) of the control firm by including the Stay indicator (and 1 - Stay indicator) uninteracted with a BR indicator but interacted with the event time indicators in equation (2). That is, we replace $\sum_{k=-3}^{6} \lambda_{k} d[k]_{i t}$ in equation (2) with $\sum_{k=-3}^{6} d[k]_{i t} \times\left(\mu_{k} \operatorname{Stay}_{i}+\right.$ $\pi_{k}\left(1-\right.$ Stay $\left.\left._{i}\right)\right)$. The results for this conditional analysis that stratifies both the bankruptcy and non-bankruptcy groups (in Online Appendix Table A4) show that both stayers and leavers of bankrupt firms lose significant earnings relative to their counterparts in non-bankrupt firms. In particular, the finding that stayers of bankrupt firms also lose considerable earnings relative to stayers of non-bankrupt firms suggests that earnings losses associated with corporate bankruptcy are beyond the losses due to a job displacement.

${ }^{18}$ Kambourov and Manovskii (2009) show that accounting for occupation-specific tenure (based on the Standard Occupational Classification), tenure in an industry (based on SIC) has a limited effect on wages, suggesting that the effect of industry switches on wages that we find may be (in part) due to occupation switches (which are likely correlated with industry switches). Unfortunately, we are unable to empirically examine this issue because the LEHD data do not contain information on the occupation of employment.
} 
selection. For example, it is possible that more able workers stay in the industry while worse workers leave, leading to the differential earnings pattern across the groups.

In terms of county stayer status, the comparison of columns (3) and (5) shows that for workers who remain in the same industry, switching counties is associated with higher postbankruptcy earnings. This finding is consistent with self-selection of workers in which those who find same-industry jobs by moving across counties would want to compensate their relocation costs and thus earn higher wages than those who stay in their initial county. Interestingly, however, the comparison of columns (4) and (6) indicates that among workers who leave the industry, those who leave the county experience a larger earnings loss than those who stay in the county (an average loss of $2 \%$ vs. $19 \%$ per year). This considerable difference appears to reflect a more onerous transition period for those who relocate across geographical areas conditional on leaving the industry.

In sum, while the analysis in this subsection does not allow us to make a statement about causality of earnings losses post-bankruptcy, it sheds light on potential drivers of the losses, such as industry-specific skills and variation in worker movements across industries and local areas.

\subsubsection{Heterogeneity Conditional on Firm Size, Local Labor Market Size, and Bankruptcy}

\section{Outcomes}

The analysis in the previous section suggests that costs to worker mobility and loss of specific human capital are potential mechanisms through which workers suffer earnings losses. To explore these mechanisms further, in this section we examine employees' post-bankruptcy earnings conditional on labor market characteristics and bankruptcy outcomes using a modified version of equation (2). Specifically, for this analysis we stratify both the treatment (bankruptcy) and control (non-bankruptcy) groups of all employees based on the conditioning variables, which 
include firm size, local labor market size, and bankruptcy outcomes. Then we compare the present value of earnings losses across the groups in Table 5, Panel B.

We first explore the effect of bankruptcy on wages conditional on the size of firms measured by employment. Workers in larger firms might fare better after bankruptcy because of better opportunities to reallocate within (e.g., to another division in the internal labor market) or across firms (Lazear and Oyer, 2004; Tate and Yang, 2015), or because of better opportunities to develop general skills that improve their job mobility. Consistent with these notions, the estimates in columns (1) and (2) of Panel B show that employees of smaller firms fare significantly worse than those of larger firms (defined as firm-level employment from the LBD larger than the third quartile) post-bankruptcy. The difference in the present value of earnings losses (-79.1\% vs. $15.6 \%$ ) is significant at the $10 \%$ level.

Second, we explore whether the impact of bankruptcy on earnings losses is related to the size of labor markets. The analysis is motivated by the extant literature arguing that large labor markets reduce search frictions and thus make it easier for workers to find jobs requiring similar skills (Diamond, 1982; Moretti, 2011). Following the labor market search literature (e.g., Petrongo and Pissaride, 2008; Manning and Petrongolo, 2017; Kim, 2018), we measure the size of the labor market at the local level. In particular, we use the number of workers in the two-digit SIC industrycounty cell from the LBD, and sort industry-county cells at the third quartile of the distribution into "large” vs. "small” (or "thick” vs. "thin”) labor markets. The results, reported in columns (3) and (4) in Table 5, Panel B, show that wages decline less in larger labor markets after bankruptcy, presumably because workers in these markets can more easily find jobs that require their skill sets. Combined with results in Panel A, these results highlight the importance of employment 
opportunities in the same industry (that presumably require similar human capital) and local area in mitigating the adverse effects of bankruptcy on labor market outcomes.

Our finding that labor market thickness affects labor market outcomes after bankruptcy complements and adds to the existing body of work that documents that displaced workers fare worse in recessions and when unemployment rates are higher, when the overall labor market is likely to be "thinner" (e.g., Davis and von Wachter, 2011). Specifically, we find evidence that cross-sectional variation (across industries and geographical areas) in labor market thickness affects earnings losses post-bankruptcy, whereas the existing work examines the role of time-series variation in labor market thickness (or conditions) in driving earnings after job displacements.

Lastly, in columns (5) through (8) we estimate the earnings patterns of employees for ultimately liquidated versus non-liquidated bankrupt firms. Given the importance of firm size in determining post-bankruptcy earning losses (columns (1) and (2)), we also condition on firm size in these tests. To the extent that workers are more likely to leave the firm after a bankruptcy that ends in liquidation, earnings losses could be greater in liquidation. In addition, liquidation may indicate poor economic or labor market conditions, under which worker reallocation is more costly, leading to greater earnings losses.

We find that the earnings losses are generally larger (in absolute magnitude) for liquidated firms than for non-liquidated firms. Columns (5) and (7) show that the PV of earnings losses amounts to $110 \%$ (of pre-bankruptcy annual earnings) for large liquidated firms but is nearly zero for large non-liquidated firms. Similarly, columns (6) and (8) show that among small firms, the PV of earnings losses is larger for liquidated than non-liquidated firms. The conditional analysis thus suggests that employee losses are more pronounced when the bankrupt firm is ultimately liquidated, and that employees of small firms fare worse whether the firm liquidates or not. 


\subsection{Economic versus Financial Distress}

Not all bankruptcies are caused by financial distress; when a business opportunity deteriorates, a firm may close even if it is financed with little debt. Since we tie our earnings loss estimates back to firms' capital structure choices in later sections, it is important to examine the extent to which the earnings losses we find are associated with financial versus economic distress. In this section, we split the full sample of bankrupt and matched firms into four groups at the medians of market leverage and ROA for bankrupt firms observed prior to bankruptcy filing. ${ }^{19}$ For each of the four groups, we estimate equation (1) using the same specification as in Table 4, Panel A, column (2). We report the present values of earnings losses for the four groups in Table 6 .

[Table 6 about here]

The first group contains firms with high leverage and high profitability, and shows a PV of earnings loss of $-59.5 \%$ (significant at the $1 \%$ level). Comparing this magnitude with the $-33.7 \%$ PV for the group with low leverage but high ROA suggests that for relatively profitable firms, high leverage before bankruptcy is associated with greater post-bankruptcy earnings losses for employees. Similarly, comparing the effects of leverage among firms with low ROA, high leverage before bankruptcy is associated with larger losses for workers (-103.6\% vs. $-87.4 \%$ for low leverage). Overall, controlling for profitability, higher firm leverage is associated with 16-26 percentage point larger PV earnings losses for workers.

When we look at the same numbers holding leverage constant, low ROA before bankruptcy is associated with greater earnings losses. For example, comparing groups 1 and 3 indicates that for highly levered firms before bankruptcy, low operating profitability implies a 44.1\% (= -103.6\%

\footnotetext{
${ }^{19}$ Andrade and Kaplan (1998, p.1445) attempt to isolate the costs of pure financial distress by investigating a subsample of ultimately bankrupt firms with high leverage and positive operating performance (measured by ROA) before bankruptcy. Brown and Matsa (2016) use ROA to control for economic performance in examining the relation between financial distress (measured by a firm's capital structure) and the number of job applications.
} 
- (-59.5\%)) greater PV of post-bankruptcy earnings losses. Comparing groups 2 and 4 indicates that for low-leverage firms, lower economic performance is associated with 53.7\% (= -87.4\% - (33.7\%)) larger earnings losses. Taken together, these conditional analyses suggest that both financial and economic distress affects employee earnings losses post-bankruptcy, with the magnitudes perhaps larger for economic distress.

In sum, the analyses in this section help us separate the impact of financial distress on employee earnings losses, which is relevant for corporate capital structure choices. In the next section, we compare our calculations to estimates of the corporate benefits of using debt, to get a sense of whether the magnitude of employee wage losses appears large enough to plausibly affect corporate financing decisions. We acknowledge that disentangling financial from economic distress is difficult, and thus interpret the results in this and the next sections as suggestive.

\section{Wage Premia for Bankruptcy Risk and Capital Structure Implications}

Employees exposed to higher risk of earnings loss (due to, for example, unemployment or moving to lower-paying jobs) would plausibly demand an ex ante wage premium to compensate for the risk (Abowd and Ashenfelter, 1981; Topel, 1984). ${ }^{20}$ In the context of bankruptcy risk, such a wage premium represents an ex ante cost of bankruptcy for the firm, creating a disincentive to use debt. To gauge whether this indirect cost of bankruptcy is of sufficient magnitude to affect corporate debt choices, in this section we first estimate the effect of leverage on wage premia by regressing wages on leverage using the LEHD data. Given that regression estimates may be affected by omitted variables, we alternatively derive wage premia using a binomial valuation

\footnotetext{
${ }^{20}$ Agrawal and Matsa (2013) point out that even if workers do not gauge their employment stability by observing direct signals of the firm's financial conditions such as financial leverage and credit ratings, they can rely on indirect signals from management, the media, and other aspects of economic conditions. Consistent with workers' ability to understand the financial status of firms, Brown and Matsa (2016) find that job seekers accurately perceive firms' financial health and act upon it by reducing labor supply to distressed firms.
} 
model. We show that implied wage premia from the wage regression and from the binomial model have comparable economic magnitudes. Lastly, we benchmark our implied wage premium to the tax benefit of debt to explore capital structure implications. ${ }^{21}$

\subsection{Estimating Annual Wage Premia Using Wage Regressions}

We first estimate annual wage premia for the risk of bankruptcy using a wage regression approach. Specifically, we estimate a standard earnings equation augmented by market leverage of the employer, a proxy for the risk of bankruptcy, as follows:

$\log (\text { earnings })_{i t}=\alpha_{j c t}+\beta \times$ Market leverage $e_{i k t}+\gamma x_{i t}+\delta z_{i k t}+\varepsilon_{i t}$,

where log(earnings) it is the logarithm of annual real earnings (in 2001 constant dollars) for worker $i$ in year $t, \alpha_{j c t}$ is industry (indexed by $\left.j\right) \times$ county $(c) \times$ year $(t)$ fixed effects, and Market leverage $i k t$ is the market leverage ratio of firm $k$ (where worker $i$ is employed) in year t. $x_{i t}$ is a set of workerlevel control variables including a female indicator, education, experience, and the interactions between every two of these three variables. $Z_{i k t}$ includes firm-level control variables: $\log ($ book assets), market-to-book, ROA, and asset tangibility for firm $k$ that employs worker $i$ in year $t$. $\varepsilon i t$ is the random error. Controlling for employee ability (using e.g., education, experience, and ROA) is important for identifying the effect of financial distress risk on wages (Berk, Stanton, and Zechner, 2010). Standard errors are clustered at the firm level.

We select a 10\% random sample of all worker-years in LEHD with ages between 22 and 50 and at least two years of tenure at current firms. ${ }^{22}$ We require that firms are on Compustat from

\footnotetext{
${ }^{21}$ Our approach uses compensating wage differentials to directly estimate the cost of financial distress resulting from the employee earnings losses due to bankruptcy. See Brown and Matsa (2016) and Baghai, Silva, Thell, and Vig (2018) for evidence that highly levered firms lose high-quality job candidates and employees due to poor job stability. Brown and Matsa (2016) also provide an empirical approach to estimate the indirect cost of financial distress due to deterioration of worker quality in financial distress.

${ }^{22}$ The $10 \%$ random sampling is to reduce computational burden in estimating the earnings equation with a large number of fixed effects, and thus is innocuous for the results.
} 
1986 to 2008, and have S\&P credit ratings between 'AA+' and 'B-' to ensure that observed earnings represent wages earned outside financial distress (Benmelech, Bergman, and Enriquez, 2012). We apply the same criterion for book assets as in the bankrupt firm sample used in Section $2 .{ }^{23}$ This procedure yields about 2.7 million worker-years employed by public firms.

[Table 7 about here]

Consistent with the existence of compensating differentials for corporate bankruptcy risk, Table 7 shows evidence that employees of firms with higher leverage are paid higher wages, all else equal. The coefficient on market leverage in column (1) suggests that a ten-percentage-point increase in leverage is associated with a $1.86 \%(=(\exp (0.171)-1) \times 10 \%)$ increase in annual earnings (significant at the $10 \%$ level). Importantly, this result is based on a sample of public firm employees from the LEHD data. Thus, our estimates refine those in Chemmanur, Cheng, and Zhang (2013), which are based on firm-level aggregate wage bills and executive compensation data. Also, our results complement Brown and Matsa (2016), who show that firms with higher risk of financial distress (proxied by CDS prices) offer higher wages to job applicants.

We next examine the heterogeneity in wage premia for employees facing different risks of losing earnings. We split the full sample at the third quartiles of firm size (measured by the number of employees) and local labor market size (measured by employment in a given two-digit SIC industry and county cell) distributions. Columns (2) and (3) show that significant wage premia exist only for workers employed by smaller firms and in smaller local labor markets. A concurrent paper by Dore and Zarutskie (2018) also estimates earnings equations using LEHD data and finds that an increase in book leverage is associated with higher wage growth, particularly in smaller (relative to larger) local labor markets. Combined with our finding in Table 5, Panel B that

\footnotetext{
${ }^{23}$ That is, we require that book assets are greater than $\$ 100$ million in 1980 constant dollars and less than or equal to the assets of the largest firm in our bankrupt firm sample.
} 
bankruptcy is associated with greater earnings losses for workers employed by smaller firms and in smaller local labor markets, the results in this section suggest that workers are paid a significant wage premium for bankruptcy risk when expected earnings loss is considerable.

One caveat of the analysis in this section is that the wage premium estimates may be biased due to omitted variables in the regression. We thus employ an alternative approach to quantify annual wage premia in the next section.

\subsection{Implied Annual Wage Premia Using a Binomial Valuation Model}

Our alternative approach to derive annual wage premia builds on the notion of compensating differentials. In a competitive labor market, firms with different risks of bankruptcy pay risk-averse employees the same risk-adjusted present value of expected wages (or provide the same level of expected utility), all else equal. In particular, the contracted wages for a firm with a higher probability of bankruptcy should be higher due to greater expected personal costs of bankruptcy for the firm's employees. This argument implies that the wage premia that a worker demands in a given year should equal the expected PV of the earnings losses due to the likelihood of her employer filling bankruptcy in that year.

Section A.1 of the online appendix details the annual wage premia demanded by an employee working for a risky firm. The appendix shows that a firm's annual wage premium relative to a risk-free firm is equal to $\frac{q\left(\frac{L}{W}\right)}{1+r_{f}}$, where $r_{f}$ is the risk-free rate, $q$ is the annual risk-adjusted (i.e., risk-neutral) bankruptcy probability, and $\frac{L}{W}$ is the present value of employee earnings losses given bankruptcy as a fraction of pre-bankruptcy wages (i.e., $67.1 \%$ as in Table 4, Panel A, column (2)). Intuitively, at the beginning of a year, a worker employed by a risky firm with an annual bankruptcy probability $q$ will face an expected wage loss of $q \times(L / W)$ by the end of the year, for 
which the worker demands a risk premium equal to its present value $\frac{q\left(\frac{L}{W}\right)}{1+r_{f}} . r_{f}$ is estimated to be 5.61\%, the average 10-year Treasury yield during our sample period of 1985-2008.

Because no direct estimate of the risk-neutral probability of bankruptcy, $q$, is available, we estimate $q$ as the risk-adjusted probability of default that Almeida and Philippon (2007) derive from bond risk premia times the conditional probability of bankruptcy given default (Prob(Bankruptcy|Default)). ${ }^{24}$ Using Moody’s Default and Recovery Database (DRD) from 1981 to 2013 , we find that $66.4 \%$ of public default firms ultimately file for bankruptcy. Similarly, the Altman-Kuehne/NYU Salomon Center Bond Master Default Database shows that $58.7 \%$ of firms in default end up filing for bankruptcy protection from 1981 to $2014 .^{25}$ Thus, we use $60 \%$ as our estimate of Prob(Bankruptcy|Default). ${ }^{26}$

Since Almeida and Philippon (2007) provide ten-year cumulative risk-adjusted default probabilities only, we convert the ten-year probability into the one-year probability. Specifically, in column (2) in Table 8, for each credit rating group, we compute the annual risk-adjusted probability of bankruptcy as $q=1-\left(1-0.6 \times p_{10}\right)^{1 / 10}$, where 0.6 is the probability of bankruptcy conditional on default discussed above, and p10 is the ten-year risk-adjusted default probability from Almeida and Philippon (2007) shown in column (1).

\footnotetext{
${ }^{24}$ The implicit assumption underlying this approach is that individual worker portfolio risk is similar to bond investors. Without detailed information on household wealth, it is difficult to know workers' overall portfolio risk. Given that there is no credible measure of workers' risk-neutral probability (which will involve proxies for the workers' marginal utility in the default state), we use the risk-neutral probability derived from bond risk premia as a proxy for it. Nevertheless, to the extent that workers' portfolio (including human capital and other financial and real assets) risk involves substantial systematic component, the risk-neutral probability derived from bond risk premia provides a reasonable proxy for the worker's risk-neutral probability. This could be due to individuals holding substantial nonhuman assets (such as financial assets) in their portfolios, and/or their labor income having a significant systematic component (see e.g., Campbell and Viceira (2002)).

${ }^{25}$ We thank Edward Altman for sharing his dataset of default events.

${ }^{26}$ Given that bankruptcy is likely to occur in bad states, the conditional risk-neutral probability may be higher than the conditional natural probability. However, the difference might be small given that default is also likely to happen in bad states. We check the sensitivity of our results by increasing the conditional probability from 0.6 to 0.9 and find that it results in the wage premium between BBB and AA-rated firms increasing from $2.32 \%$ to $3.17 \%$, suggesting little sensitivity of our results to the conditional probability.
} 


\section{[Table 8 about here]}

We then use the annual risk-adjusted bankruptcy probability, $q$, to calculate the implied annual wage premium as a fraction of wages paid by the firm $: \frac{q\left(\frac{L}{W}\right)}{1+r_{f}}$. Column (3) in Table 8 shows that the implied annual wage premium accounts for a considerable portion of annual wages, particularly for firms with low credit ratings. The implied annual wage premium accounts for $0.26 \%$ of annual wages for AA-rated firms and $0.84 \%$ for BBB-rated firms.

\subsection{Comparing Regression-Based and Implied Annual Wage Premia}

In this section, we compare the implied annual wage premium derived from the binomial valuation model in Section 4.2 to the annual wage premium estimated from the wage regression in Section 4.1. Given that our wage regression does not benchmark with risk-free firms, we use AA-rated firms as a benchmark for our regression-based wage premia estimates. As such, Table 9 compares the annual wage premia that BBB-rated firms pay relative to AA-rated firms between these two approaches. Full sample comparisons are in column (1), while columns (2) and (3) show comparisons for subsamples based on firm employment and columns (4) and (5) are based on labor market size.

Panel A shows that using the binomial valuation model, the additional implied annual wage premium due to moving from $\mathrm{AA}$ to $\mathrm{BBB}$ rating is $0.58 \%$ of annual wages for the full sample. We derive the implied annual wage premia for subsamples in columns (2) through (5) similarly following the process explained in Section 4.2, except that we use the PV earnings loss estimates for those subsamples from Table 5, Panel B, columns (1) through (4) (e.g., -79.1\% of prebankruptcy earnings for employees of smaller firms). As shown in the table, the implied annual wage premia are larger in subsamples for which the post-bankruptcy earnings losses are greater (i.e., for smaller firms and smaller labor markets). 
[Table 9 about here]

Next, we derive the differential wage premium between BBB and AA-rated firms using the wage regression results and report the estimates in Table 9, Panel B. We begin with the coefficient on market leverage in column (1) of Table 7 (0.171), which suggests that a onepercentage-point increase in leverage is associated with a $0.186 \%(=\exp (0.171)-1)$ increase in annual earnings. We then calculate the difference in leverage between BBB and AA-rated firms in our sample, controlling for the difference in other firm characteristics used in the earnings regression in Table 7 . This leverage difference is equal to $2.3 \%{ }^{27}$ Lastly, the differential wage premium between $\mathrm{BBB}$ and $\mathrm{AA}$-rate firms is equal to the leverage difference (2.3\%) times the coefficient on leverage in the wage regression $(0.186)$, the product of which is $0.43 \%$. The wage premia for subsamples are calculated similarly except that we use coefficients on leverage for different subsamples in Table 7, column (2) or (3).

Comparing Panels A and B of Table 9 shows that the differences in annual wage premia between BBB and AA-rated firms are similar when we use the two different approaches. In addition, Panel B reinforces the conclusion obtained from Panel A that wage premia are larger when employees face potentially larger earnings losses from bankruptcy (i.e., for smaller firms and for firms operating in smaller local labor markets). ${ }^{28}$

\subsection{Implied Wage Premia and Capital Structure Implications}

In this section, we build upon the implied annual wage premia for risky firms (relative to risk-free firms) based on the binomial valuation model (Section 4.2) and compute the capitalized value of implied wage premia for firms with different credit ratings (relative to risk-free firms).

\footnotetext{
${ }^{27}$ Specifically, we regress market leverage on credit rating indicators (from 'AA+' to 'B-') and firm characteristics in equation (3), and take the difference between the coefficients on the BBB and the AA indicators.

${ }^{28}$ Consistent with this finding for labor market size, Kim (2018) shows that leverage is lower for firms operating in smaller labor markets.
} 
The capitalized wage premia, interpreted as indirect costs of financial distress, are then compared with tax benefits of debt for firms with different credit ratings. We are not able to compute the capitalized wage premia over risk-free firms using the wage regression approach (Section 4.1) because the wage regression is conducted on firms with credit risk. ${ }^{29}$

\subsubsection{Capitalized Value of Implied Wage Premia as Indirect Costs of Financial Distress}

Given that tax benefits of debt are often measured as a fraction of firm value (e.g., Graham, 2000), we compute the capitalized value of implied wage premia as a fraction firm value. First, we convert the annual wage premium as a fraction of wages (Section 4.2), $\frac{q\left(\frac{L}{W}\right)}{1+r_{f}}$, into the annual premium as a fraction of market value of the firm as $\frac{q\left(\frac{L}{M V}\right)}{1+r_{f}}=\frac{q\left(\frac{L}{W}\right)}{1+r_{f}} \times \frac{W}{M V}$, where $\frac{W}{M V}$ is the ratio of total wage bill and market value of the average firm in t-4. Second, we compute the present value of the annual wage premium for a firm with an infinite horizon, and derive that the firm's capitalized value of wage premia relative to a risk-free firm as a fraction of firm value is equal to $\frac{q\left(\frac{L}{M V}\right)}{r_{f}+q}$ (see Section A.2 of the online appendix for details). ${ }^{30}$

\section{[Table 10 about here]}

Column (1) in Table 10 shows the annual wage premium as a fraction of firm value for firms with different credit ratings. Column (2) shows that the capitalized value of the wage premium is a nontrivial fraction of firm value, particularly for firms with low credit ratings. The present value of the wage premium is $1.29 \%$ of firm value for AA-rated firms, and increases to 3.61\% for BBB-rated firms. The increase in wage premia for firms with lower credit ratings (and

\footnotetext{
${ }^{29}$ We benchmark against risk-free firms in calculating the PV of annual wage premia because the existing estimates on expected costs of financial distress and tax benefits are relative to risk-free firms.

${ }^{30}$ Almeida and Philippon (2007) use similar valuation models and risk-adjusted default probabilities to compute the expected costs of financial distress (but they do not address employee costs or the wage premia that we compute).
} 
thus higher leverage) may potentially offset the increased tax benefits of debt for these more highly-levered firms. In the next subsection, we explore the implications of bankruptcy-induced wage premia for capital structure decisions.

\subsubsection{Comparing Implied Wage Premia to Tax Benefits of Debt and Expected Costs of Financial Distress}

Comparing columns (2) and (3) in Table 10 indicates that the present value of implied wage premia is a significant fraction of the tax benefits of debt. For AA and BBB-rated firms, tax benefits of debt equal $2.51 \%$ and $5.18 \%$ of firm value, respectively, while wage premia are $1.29 \%$ and $3.61 \%$ of firm value. Thus, wage premia offset $51 \%$ and $70 \%$ of the tax benefits of debt for AA and BBB-rated firms, which is of large enough magnitude to affect capital structure choices.

To further assess the importance of wage premia, we explicitly factor in non-wage costs of financial distress by benchmarking implied wage premia with the tax benefits, net of the expected financial distress costs estimated by Almeida and Philippon (2007) and Elkamhi, Ericsson, and Parsons (2012). Both papers use risk-neutral probabilities to estimate expected costs of financial distress. However, as Elkamhi et al. (2012) point out, Almeida and Philippon (2007) may overstate the expected costs of financial distress by applying Andrade and Kaplan’s (1998) 10-23\% proportional losses to the firm's current (i.e., far outside default) value. In contrast, Elkamhi et al. (2012) use the firm's value near default, on which Andrade and Kaplan (1998) derive their 10-23\% estimates. As a result, the expected distress cost estimates from Elkamhi et al. (2012) are considerably smaller than those from Almeida and Philippon (2007). For example, Elkamhi et al. (2012) find that a BBB-rated firm's expected costs of financial distress are only 0.5\% of firm value, which is significantly smaller than 4.53\% in Almeida and Philippon (2007). 
Based on the estimates from Elkamhi et al. (2012), when a firm's credit rating decreases from AA to BBB, the gap between the tax benefits of debt and expected cost of financial distress increases by $2.17 \%$ (= $2.67 \%-0.5 \%$, last row of columns (3) and (5) in Table 10$)$. This is close to our estimate of the difference in the wage premium of 2.32\% between BBB and AA-rated firms (last row of column (2)). Therefore, our estimated wage premium appears to account for a substantial portion of the gap between tax benefits of debt and the expected cost of financial distress documented in the literature.

We note that our estimates of wage premium are larger than those in Agrawal and Matsa (2013, AM). AM find that, assuming no wage replacement by unemployment insurance (UI) benefits, firms with AA-ratings and BBB-ratings respectively pay $0.16 \%$ and $1.54 \%$ wage premiums. ${ }^{31}$ Matsa (2018) argues that the differences between AM’s (2013) estimates and ours are understandable for several reasons. For example, Matsa (2018) points out that AM's estimates account for unemployment risk only, while our estimates also include earnings losses for employees who stay with a bankrupt firm (see Online Appendix Table A4). Also, our estimates include wage losses following an unemployment spell. These differences help explain the somewhat larger magnitude of our wage premium estimates relative to AM's.

Overall, our estimates for wage premia associated with bankruptcy risk are large enough to be an important component of financial distress costs (Titman (1984) and Berk et al. (2010)), which may help to explain the debt conservatism puzzle.

\section{Conclusion}

\footnotetext{
${ }^{31}$ Agrawal and Matsa (2013, Table 8) also provide estimates that assume average UI wage replacement, for which the magnitude is about $37 \%$ of those assuming no UI replacement. We also conduct analysis of the impact of UI on our estimation and find that, accounting for UI, the PV of earnings losses is 59.5\% of pre-bankruptcy earnings (vs. $67.1 \%$ in our baseline estimates). We thank David Matsa for generously providing data on state UI benefits for this analysis.
} 
We examine how corporate bankruptcy leads to employee earnings losses due to adjustments in labor markets. We use worker-firm matched data from the U.S. Census Bureau to show that employee earnings deteriorate significantly for six years post-bankruptcy. The present value of earnings losses accumulated over seven years averages $67 \%$ of pre-bankruptcy annual earnings. Earnings losses are larger for individuals who leave the industry, and who work for smaller firms or in thinner local labor markets. These results highlight the role of industry-specific human capital and costs of moving across geographical areas as important forces behind the postbankruptcy earnings loss.

Given that a firm's debt choice affects the probability of bankruptcy, we argue that these workforce costs circle back to high-leverage companies in the form of higher ex ante contracted wages. We show that the ex-ante wage premium that firms must pay to compensate for the expected earnings loss due to bankruptcy is a considerable fraction of the magnitude of the tax benefits of debt. Thus, our results suggest that these indirect bankruptcy costs borne by employees are significant enough to be a first-order consideration when firms make capital structure choices. 


\section{References:}

Abowd, John M. and Orley C. Ashenfelter, 1981, Anticipated Unemployment, Temporary Layoffs, and Compensating Wage Differentials, NBER Chapters, in: Studies in Labor Markets, pp. 141-186, National Bureau of Economic Research.

Abowd, John M., Bryce E. Stephens, Lars Vilhuber, Fredrik Andersson, Kevin L. McKinney, Marc Roemer, and Simon Woodcock, 2009, The LEHD Infrastructure Files and the Creation of the Quarterly Workforce Indicators, in: T. Dunne, J.B. Jensen and M.J. Roberts, eds., Producer Dynamics: New Evidence from Micro Data (Chicago: University of Chicago Press for the National Bureau of Economic Research, 2009), pp. 149-230.

Agrawal, Ashwini K. and David A. Matsa, 2013, Labor Unemployment Risk and Corporate Financing Decisions, Journal of Financial Economics 108, 449-470.

Almeida, Heitor and Thomas Philippon, 2007, The Risk-Adjusted Cost of Financial Distress, Journal of Finance 62, 2557-2586.

Andrade, Gregor and Steven N. Kaplan, 1998, How Costly is Financial (not Economic) Distress? Evidence from Highly Levered Transactions that Became Distressed, Journal of Finance 53, 1443-1493.

Autor, David H., David Dorn, Gordon H. Hanson, and Jae Song, 2014, Trade Adjustment: Worker-Level Evidence, Quarterly Journal of Economics 129, 1799-1860.

Azariadis, Costas, 1975, Implicit Contracts and Underemployment Equilibria, Journal of Political Economy 83, 1183-1202.

Baghai, Ramin, Rui Silva, Viktor Thell, and Vikrant Vig, 2018, Talent in Distressed Firms: Investigating the Labor Costs of Financial Distress, Working paper, Stockholm School of Economics and London Business School.

Baily, Martin N., 1974, Wages and Employment under Uncertain Demand, Review of Economic Studies 41, 37-50.

Becker, Gary S., 1962, Investment in Human Capital: A Theoretical Analysis, Journal of Political Economy 70, 9-49.

Benmelech, Efraim, Nittai K. Bergman, and Ricardo J. Enriquez, 2012, Negotiating with Labor under Financial Distress, Review of Corporate Finance Studies 1, 28-67.

Berk, Jonathan, Richard Stanton, and Josef Zechner, 2010, Human Capital, Bankruptcy, and Capital Structure, Journal of Finance 65, 891-926.

Bernstein, Shai, Emanuele Colonnelli, and Benjamin Iverson, 2019, Asset Allocation in Bankruptcy, Journal of Finance 74, 5-53.

Brown, Jennifer and David Matsa, 2016, Boarding a Sinking Ship? An Investigation of Job Applications to Distressed Firms, Journal of Finance 71, 507-550. 
Butt-Jaggia, Priscilla and Anjan V. Thakor, 1994, Firm-Specific Human Capital and Optimal Capital Structure, International Economic Review 35, 283-308.

Campbell, John Y. and Luis M. Viceira, 2002, Strategic Asset Allocation. London, U.K.: Oxford University Press.

Chemmanur, Thomas J., Yingmei Cheng, and Tianming Zhang, 2013, Human Capital, Capital Structure, and Employee Pay: An Empirical Analysis, Journal of Financial Economics 110, 478-502.

Couch, Kenneth A. and Dana W. Placzek, 2010, Earnings Losses of Displaced Workers Revisited, American Economic Review 100, 572-589.

Davis, Steven J. and Till von Wachter, 2011, Recessions and the Costs of Job Loss, Brookings Papers on Economic Activity, 1-72.

Diamond, Peter A., 1982, Aggregate Demand Management in Search Equilibrium, Journal of Political Economy 90, 881-894.

Dore, Timothy E. and Rebecca Zarutskie, 2018, Firm Leverage, Labor Market Size, and Employee Pay, Working paper, Federal Reserve Board.

Eckbo, B. Espen, Karin S. Thorburn, and Wei Wang, 2016, How Costly is Corporate Bankruptcy for the CEO?, Journal of Financial Economics 121, 210-229.

Elkamhi, Redouane, Jan Ericsson, and Christopher A. Parsons, 2012, The Cost and Timing of Financial Distress, Journal of Financial Economics 105, 62-81.

Falato, Antonio and J. Nellie Liang, 2016, Do Creditor Rights Increase Employment Risk? Evidence from Loan Covenants, Journal of Finance 71, 2545-2590.

Gilson, Stuart, 1989, Management Turnover and Financial Distress, Journal of Financial Economics 25, 241-262.

Goyal, Vidhan K. and Wei Wang, 2017, Provision of Management Incentives in Bankrupt Firms, Journal of Law, Finance, and Accounting 2, 87-123.

Graham, John R., 2000, How Big are the Tax Benefits of Debt?, Journal of Finance 55, 1901-1941.

Guiso, Luigi, Luigi Pistaferri, and Fabiano Schivardi, 2005, Insurance within the Firm, Journal of Political Economy 113, 1054-1087.

Hotchkiss, Edith S., 1995, Post-bankruptcy Performance and Management Turnover, Journal of Finance 50, 3-21.

Hummels, David, Rasmus Jorgensen, Jakob Munch, and Chong Xiang, 2014, The Wage Effects of Offshoring: Evidence from Danish Matched Worker-Firm Data, American Economic Review 104, 1597-1629.

Imbens, Guido W. and Donald B. Rubin, 2015, Causal Inference for Statistics, Social, and Biomedical Sciences: An Introduction. New York: Cambridge University Press. 
Jacobson, Louis S., Robert J. LaLonde, and Daniel G. Sullivan, 1993, Earnings Losses of Displaced Workers, American Economic Review 83, 685-709.

Jiang, Wei, Kai Li, and Wei Wang, 2012, Hedge Funds and Chapter 11, Journal of Finance 67, 513-560.

Kambourov, Gueorgui and Iourii Manovskii, 2009, Occupational Specificity of Human Capital, International Economic Review 50, 63-115.

Kim, Hyunseob, 2018, How Does Labor Market Size Affect Firm Capital Structure? Evidence from Large Plant Openings, Working paper, Cornell University.

Kodrzycki, Yolanda K., 2007, Using Unexpected Recalls to Examine the Long-Term Earnings Effects of Job Displacement, Working paper, Federal Reserve Bank of Boston.

Lazear, Edward P. and Paul Oyer, 2004, Internal and External Labor Markets: A Personnel Economics Approach, Labour Economics 11, 527-554.

LoPucki, Lynn M. and William C. Whitford, 1992, Patterns in the Bankruptcy Reorganization of Large, Publicly Held Companies, Cornell Law Review 78, 597-618.

Manning, Alan and Barbara Petrongolo, 2017, How Local Are Labour Markets? Evidence from a Spatial Job Search Model, American Economic Review 83, 2877-2907.

Matsa, David A., 2018, Capital Structure and a Firm's Workforce, Annual Review of Financial Economics 10, 387-412.

Moretti, Enrico, 2011, Local labor markets, Handbook of Labor Economics, Elsevier, N.H.

Neal, Derek, 1995, Industry-Specific Human Capital: Evidence from Displaced Workers, Journal of Labor Economics 13, 653-677.

Schoeni, Robert F. and Michael Dardia, 2003, Estimates of Earnings Losses of Displaced Workers Using California Administrative Data, Working paper, RAND and Public Policy Institute of California.

Sullivan, Daniel and Till von Wachter, 2009, Job Displacement and Mortality: An Analysis Using Administrative Data, Quarterly Journal of Economics 124, 1265-1306.

Tate, Geoffrey and Liu Yang, 2015, The Bright Side of Corporate Diversification: Evidence from Internal Labor Markets, Review of Financial Studies 28, 2203-2249.

Titman, Sheridan, 1984, The Effect of Capital Structure on a Firm's Liquidation Decision, Journal of Financial Economics 13, 137-151.

Topel, Robert H., 1984, Equilibrium Earnings, Turnover, and Unemployment: New Evidence, Journal of Labor Economics 2, 500-522.

Vilhuber, Lars and Kevin L. McKinney, 2014, LEHD Data Documentation LEHD-Overview-S2011: LEHD Infrastructure Files in the Census RDC - Overview, CES Working paper 14-26.

von Wachter, Till, Jae Song, and Joyce Manchester, 2011, Long-Term Earnings Losses due to Mass Layoffs

During the 1982 Recession: An Analysis Using U.S. Administrative Data from 1974 to 2004, 
Working paper, Columbia University, Social Security Administration, and Congressional Budget Office.

von Wachter, Till, Elizabeth Handwerker, and Andrew K. G. Hildreth, 2009, Estimating the 'True' Cost of Job Loss: Evidence using Matched Data from California 1991-2000, Working paper, Columbia University, Bureau of Labor Statistics, and University of California at Berkeley.

Walker, W. Reed, 2013, The Transitional Costs of Sectoral Reallocation: Evidence from the Clean Air Act and the Workforce, Quarterly Journal of Economics 128, 1787-1835. 


\section{Appendix - Definition of Variables}

\section{Variable Name Variable Definition}

Firm characteristics

\section{Sales}

Book assets

Market assets

Book (Market) leverage

ROA

Market-to-book

Number of employees

Credit rating

Asset tangibility

Worker characteristics

Female

Years of experience

Years of education
Total sales of the firm in \$millions

Total book value of assets in \$millions

Book assets + market equity - book equity

Total debt/book (market) assets, where total debt = long term plus short-term debt

Operating income before depreciation and amortizations/lagged book assets

(Total debt + market equity)/(total debt + book equity)

Number of employees in the firm, obtained from Longitudinal Business Database (LBD)

S\&P credit rating from Compustat

Net PP\&E/book assets

Dependent and main independent variables

Log (earrings)

BR

$\mathrm{d}[\mathrm{k}]$, where $\mathrm{k}=-3$ to +6
Natural logarithm of annual earnings from LEHD-EHF adjusted for inflation using the CPI (in 2001 constant dollars)

An indicator variable equal to one for employees of bankrupt firms and zero for employees of control firms

Event year indicator variables from three years before to six years after bankruptcy 


\section{Figure 1: Effect of Corporate Bankruptcy on Employee Earnings}

The figure uses the difference-in-difference estimates in Table 4, Panel A, column (2) and presents the percentage change in real earnings (solid line) for employees of bankrupt firms from the benchmark (i.e., t-4) earnings, relative to the earnings change for employees of matched firms. The dashed lines represent $95 \%$ confidence intervals. "Year t” represents the year of bankruptcy filing.

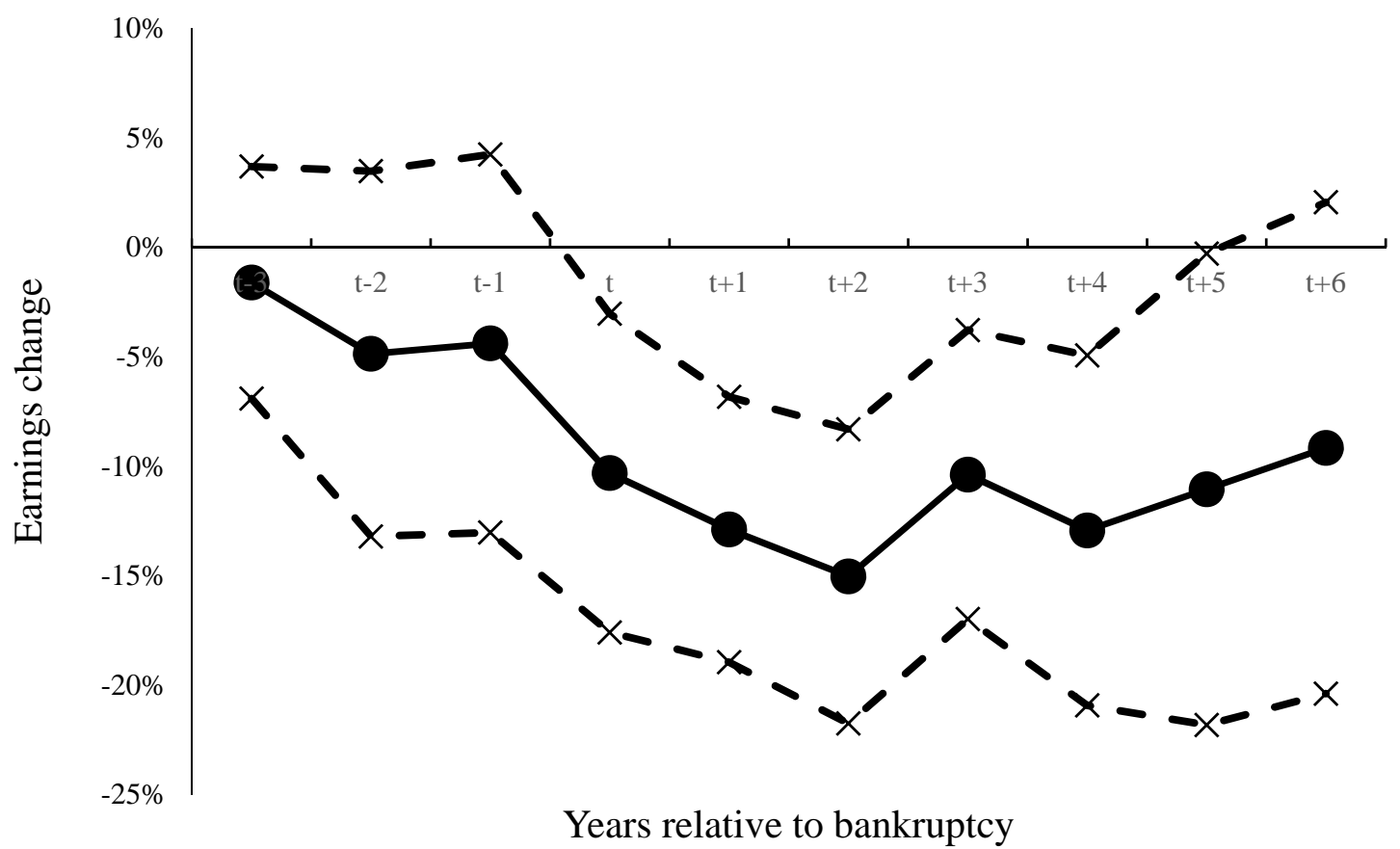




\section{Table 1: Coverage of LEHD States and Years}

This table presents the coverage of states and years by the U.S. Census Bureau's Longitudinal Employer-Household Dynamics (LEHD)-Employment History File (EHF). See Vilhuber and McKinney (2014) for details of the LEHD infrastructure.

\begin{tabular}{lccc}
\hline \hline \multicolumn{1}{c}{ State } & State abbreviation & First year & Last year \\
\hline Arkansas & AR & 2002 & 2008 \\
California & CA & 1991 & 2008 \\
Colorado & CO & 1990 & 2008 \\
Florida & FL & 1992 & 2008 \\
Georgia & GA & 1994 & 2008 \\
Hawaii & HI & 1995 & 2008 \\
Iowa & IA & 1998 & 2008 \\
Idaho & ID & 1990 & 2008 \\
Illinois & IL & 1990 & 2008 \\
Indiana & IN & 1990 & 2008 \\
Louisiana & LA & 1990 & 2008 \\
Maryland & MD & 1985 & 2008 \\
Maine & ME & 1996 & 2008 \\
Montana & MT & 1993 & 2008 \\
North Carolina & NC & 1991 & 2008 \\
North Dakota & ND & 1998 & 2008 \\
Nevada & NV & 1998 & 2008 \\
New Jersey & NJ & 1996 & 2008 \\
New Mexico & NM & 1995 & 2008 \\
Oklahoma & OK & 2000 & 2008 \\
Oregon & OR & 1991 & 2008 \\
Rhode Island & RI & 1995 & 2008 \\
South Carolina & SC & 1998 & 2008 \\
Texas & TX & 1995 & 2008 \\
Utah & UT & 1999 & 2008 \\
Virginia & VA & 1998 & 2008 \\
Vermont & VT & 2000 & 2008 \\
Washington & WA & 1990 & 2008 \\
Wisconsin & WI & 1990 & 2008 \\
West Virginia & WV & 1997 & 2008 \\
\hline \hline & & & \\
\hline
\end{tabular}




\section{Table 2: Descriptive Statistics on Firm Characteristics of Bankrupt and Matched Firms}

This table presents descriptive statistics on characteristics of bankruptcy events, firms and their matched firms. Panel A presents bankruptcy outcomes for the full sample of the bankrupt firms in the LoPucki Bankruptcy Research Database (BRD) from 1990 to 2005 and the bankrupt firms with at least ten employees in the Census Bureau's Longitudinal Employer-Household Dynamics (LEHD) database. Panel B compares firm characteristics of bankrupt and propensity-score matched firms, with the statistics based on the values in the latest fiscal year before bankruptcy (usually year t- 1 or t-2, where "year t” is the year of bankruptcy filing or matching). Panel C presents the descriptive statistics on dynamics of firm characteristics for bankrupt and matched firms from years t-3 to t-1. See the Appendix for variable definitions. Statistical significance at the $10 \%, 5 \%$, and $1 \%$ levels is indicated by ${ }^{*}{ }^{* *}$, and ${ }^{* * *}$.

\section{Panel A: Bankruptcy Outcomes}

\begin{tabular}{|c|c|c|c|c|}
\hline & \multicolumn{2}{|c|}{ All bankrupt firms from BRD } & \multicolumn{2}{|c|}{ "Bankrupt firms with employees in LEHD } \\
\hline & N. events & \% of sample & N. events & \% of sample \\
\hline Merged, acquired, or continue & 224 & $43.9 \%$ & 59 & $42.3 \%$ \\
\hline Liquidated, closed, or refile Chapter 11 & 106 & $20.8 \%$ & 24 & $16.9 \%$ \\
\hline Unknown & 180 & $35.3 \%$ & 57 & $40.9 \%$ \\
\hline Total & 510 & $100 \%$ & 140 & $100 \%$ \\
\hline
\end{tabular}

Panel B: Firm Characteristics of Bankrupt and Matched Firms

\begin{tabular}{|c|c|c|c|c|c|c|c|c|}
\hline \multirow{3}{*}{ Variable } & \multicolumn{2}{|c|}{$\begin{array}{c}\text { Bankrupt firms with } \\
\text { information from } \\
\text { Compustat/SSEL }\end{array}$} & \multicolumn{2}{|c|}{$\begin{array}{l}\text { Bankrupt firms with } \\
\text { employees in LEHD }\end{array}$} & \multicolumn{2}{|c|}{$\begin{array}{l}\text { Propensity-score } \\
\text { matched firms }\end{array}$} & \multicolumn{2}{|c|}{$\begin{array}{l}\text { Difference } \\
\text { (3)-(5) }\end{array}$} \\
\hline & (1) & $(2)$ & (3) & (4) & (5) & (6) & (7) & (8) \\
\hline & Mean & STD & Mean & STD & Mean & STD & Mean & t-statistics \\
\hline Sales (\$m) & 1,537 & 6,113 & 1,669 & 3,509 & 1,416 & 3,818 & 253 & 0.57 \\
\hline Book assets (\$m) & 1,390 & 4,244 & 1,320 & 1,820 & 1,106 & 1,723 & 214 & 0.89 \\
\hline Market assets (\$m) & 1,185 & 4,333 & 992 & 1,265 & 1,228 & 2,859 & -236 & -0.73 \\
\hline Number of employees & 8,672 & 20,920 & 11,080 & 24,970 & 13,920 & 36,130 & $-2,840$ & -0.53 \\
\hline Book leverage & 0.63 & 0.37 & 0.57 & 0.24 & 0.30 & 0.21 & 0.27 & $9.74^{* * *}$ \\
\hline Market leverage & 0.57 & 0.26 & 0.57 & 0.23 & 0.30 & 0.21 & 0.27 & $9.74^{* * *}$ \\
\hline ROA & 0.00 & 0.31 & 0.06 & 0.07 & 0.06 & 0.07 & -0.01 & -1.02 \\
\hline Market-to-book & 1.18 & 0.87 & 1.14 & 0.86 & 1.21 & 1.14 & -0.07 & -0.58 \\
\hline N. events & 360 & - & 140 & - & 140 & - & - & - \\
\hline
\end{tabular}


Panel C. Dynamics of Firm Characteristics for Bankrupt and Matched Firms Prior to Bankruptcy

\begin{tabular}{|c|c|c|c|c|c|c|c|c|c|}
\hline \multirow[b]{2}{*}{ Year } & \multicolumn{3}{|c|}{$\begin{array}{c}\text { (1) } \\
\text { Bankrupt firms } \\
\end{array}$} & \multicolumn{3}{|c|}{$\begin{array}{c}\text { (2) } \\
\text { Matched firms } \\
\end{array}$} & \multicolumn{3}{|c|}{$t$-statistics for (1)-(2) } \\
\hline & $\mathrm{t}-3$ & $\mathrm{t}-2$ & $\mathrm{t}-1$ & $\mathrm{t}-3$ & $\mathrm{t}-2$ & $\mathrm{t}-1$ & $t-3$ & $\mathrm{t}-2$ & $\mathrm{t}-1$ \\
\hline Sales (\$m) & 1,595 & 1,681 & 1,643 & 1,032 & 1,176 & 1,276 & 1.54 & 1.23 & 0.82 \\
\hline Book assets (\$m) & 1,398 & 1,479 & 1,427 & 943 & 1,061 & 1,117 & $1.87^{*}$ & 1.64 & 1.18 \\
\hline Market assets (\$m) & 1,403 & 1,206 & 1,004 & 1,107 & 1,094 & 1,210 & 1.01 & 0.43 & -0.67 \\
\hline Number of employees & 11,510 & 11,900 & 10,960 & 14,810 & 14,400 & 13,390 & -0.55 & -0.47 & -0.52 \\
\hline Book leverage & 0.44 & 0.49 & 0.57 & 0.25 & 0.27 & 0.30 & $6.32^{* * *}$ & $7.18^{* * *}$ & $8.74^{* * *}$ \\
\hline Market leverage & 0.38 & 0.45 & 0.57 & 0.21 & 0.25 & 0.30 & $5.84^{* * *}$ & $7.00^{* * *}$ & $8.98^{* * *}$ \\
\hline ROA & 0.12 & 0.10 & 0.06 & 0.12 & 0.10 & 0.06 & -0.50 & -0.25 & -0.49 \\
\hline Market-to-book & 1.60 & 1.28 & 1.06 & 1.70 & 1.37 & 1.21 & -0.71 & -0.62 & -1.14 \\
\hline
\end{tabular}




\section{Table 3: Descriptive Statistics on Employees Characteristics of Bankrupt and Matched Firms}

This table presents descriptive statistics of the workers employed by bankrupt and control firms. All variables are measured at $\mathrm{t}-1$ (where "year t" is the year of bankruptcy filing or matching). The earnings data for individual employees are from the LEHD-EHF (Employment History Files), and other individual characteristics are from the LEHD-ICF (Individual Characteristics Files). We require that workers have at least two years of tenure and ages between 22 and 50 years in year t-1. Columns (5) and (6) show statistics for a 1\% random sample of workers from the LEHD-EHF data who are employed by non-bankrupt public firms, are not displaced, and satisfy the same requirements for industry (i.e., excluding financials and utilities), tenure, and age as the workers in the bankruptcy sample. Earnings are CPI-adjusted (in 2001 constant dollars). "\% stay in firm (before)" (industry or county) is the percent of employees who stay in the bankrupt firm (the employee's industry or county) from t-4 to t-1. Similarly, "\% stay in firm (after)" (industry or county) is the percent of employees who stay in the bankrupt firm (the employee's industry or county) from t-1 to $t+3$. " $\Delta \%$ stay in firm (before $\rightarrow$ after)" (industry or county) is the change in the percent of employees who stay in the bankrupt firm (the employee's industry or county) between t-4 to t- 1 and t- 1 to $t+3$. Definitions of variables are in the Appendix. Columns (7) and (8) report heteroskedasticity robust $t$-statistics adjusted for within-firm clustering. Statistical significance at the $10 \%, 5 \%$, and $1 \%$ levels is indicated by ${ }^{*}{ }^{* *}$, and ${ }^{* * *}$. The number of employees is rounded to the nearest thousand to follow the Census Bureau's disclosure rules.

\begin{tabular}{|c|c|c|c|c|c|c|c|c|}
\hline & \multicolumn{2}{|c|}{$\begin{array}{c}\text { Employees of } \\
\text { bankrupt firms }\end{array}$} & \multicolumn{2}{|c|}{$\begin{array}{l}\text { Employees of } \\
\text { matched firms }\end{array}$} & \multicolumn{2}{|c|}{$\begin{array}{c}\text { Randomly } \\
\text { selected workers }\end{array}$} & \multirow{2}{*}{$\begin{array}{c}\text { t-statistic } \\
\text { for (1)-(3) } \\
(7)\end{array}$} & \multirow{2}{*}{$\begin{array}{c}\text { t-statistic } \\
\text { for (1)-(5) } \\
\text { (8) }\end{array}$} \\
\hline & $\begin{array}{c}(1) \\
\text { Mean } \\
\end{array}$ & $\begin{array}{c}(2) \\
\text { STD }\end{array}$ & $\begin{array}{c}(3) \\
\text { Mean } \\
\end{array}$ & $\begin{array}{l}(4) \\
\text { STD }\end{array}$ & $\begin{array}{c}(5) \\
\text { Mean } \\
\end{array}$ & $\begin{array}{c}(6) \\
\text { STD }\end{array}$ & & \\
\hline Years of education & 13.42 & 2.35 & 13.43 & 2.39 & 13.41 & 2.42 & -0.09 & 0.04 \\
\hline Age & 36.21 & 8.21 & 36.22 & 8.35 & 35.23 & 8.15 & -0.01 & 1.58 \\
\hline Years of experience & 16.79 & 8.00 & 16.79 & 8.09 & 15.82 & 7.96 & 0.00 & $1.97^{* *}$ \\
\hline Female & 50.8 & 50.0 & 42.4 & 49.4 & 45.5 & 49.8 & 1.43 & 1.28 \\
\hline Annual real earnings at t-1 (2001\$) & 34,250 & 83,940 & 34,440 & 36,210 & 33,810 & 70,140 & -0.02 & 0.08 \\
\hline Number of employees & 277,000 & - & 353,000 & - & 476,000 & - & - & - \\
\hline \% stay in firm (before) & 51.5 & - & 50.1 & - & - & - & 0.12 & - \\
\hline \% stay in industry (before) & 72.8 & - & 67.4 & - & - & - & 0.82 & - \\
\hline \% stay in county (before) & 71.1 & - & 64.1 & - & - & - & 0.96 & - \\
\hline \% stay in firm (after) & 37.2 & - & 47.5 & - & 56.5 & - & -1.04 & $-3.46^{* * *}$ \\
\hline \% stay in industry (after) & 54.4 & - & 64.6 & - & 68.9 & - & -1.50 & $-3.87^{* * *}$ \\
\hline \% stay in county (after) & 56.0 & - & 66.1 & - & 69.7 & - & -1.46 & $-3.85^{* * *}$ \\
\hline$\Delta \%$ stay in firm (before $\rightarrow$ after) & -14.3 & - & -2.6 & - & - & - & -1.05 & - \\
\hline$\Delta \%$ stay in industry (before $\rightarrow$ after) & -18.4 & - & -2.8 & - & - & - & $-2.66^{* *}$ & - \\
\hline$\Delta \%$ stay in county (before $\rightarrow$ after) & -15.1 & - & 2.0 & - & - & - & $-2.79^{* * *}$ & - \\
\hline
\end{tabular}




\section{Table 4: Effect of Corporate Bankruptcy on Employee Earnings}

This table presents difference-in-difference estimates of earnings changes for workers employed by bankrupt firms around bankruptcy filings relative to a control group of workers. The control group in Panel A includes employees of the matched firms, and in Panel B a 1\% random sample of non-displaced workers from the LEHD universe employed by public non-bankrupt firms. Panel $\mathrm{C}$ reports the present value of earnings losses using matched firm's employees as the control group and after imputing missing earnings in LEHD. The dependent variable is log(annual earnings) in 2001 constant dollars. "BR" is an indicator variable equal to one for employees of bankrupt firms. The event year indicator variables are "d[k]," where $-3 \leq \mathrm{k} \leq 6$. The regressions use the observations from event years $\mathrm{t}-4$ to $\mathrm{t}+6$, with the benchmark earnings being the earnings in year $t-4$. Standalone event year indicators $d[k](-3 \leq k \leq 6)$ are included in all regressions but suppressed for expositional convenience. "PV (Earnings losses)" is the present value of earnings losses from years $t$ to $t+6$ (computed using a real discount rate of 5.48\%) as a percent of the pre-bankruptcy annual earnings in t-4. To illustrate the process to compute the PV, take Panel A, column (2) as an example. We first convert the coefficient on "d $[1] \times \mathrm{BR}$, " -0.129 , into $\exp (-0.129)-1=-12.1 \%$, which is the percentage change in earnings when $\mathrm{d}[1] \times \mathrm{BR}$ changes from zero to one. We then discount the percentage change by a year using a real discount rate. We repeat the calculation for all coefficients on "d[k] $\times \mathrm{BR}$ " for $0 \leq \mathrm{k} \leq 6$, and then sum up the present values across the seven years. For regression coefficients, heteroskedasticity robust $t$-statistics adjusted for within-firm clustering are in parentheses. Definitions of variables are in the Appendix. For present values of earnings losses, $t$ statistics for the PV significantly differing from zero are in parentheses (standard errors are computed using the delta method). Statistical significance at the $10 \%, 5 \%$, and $1 \%$ levels is indicated by ${ }^{*}$, ${ }^{* *}$, and ${ }^{* * *}$. The number of observations is rounded to the nearest thousand to follow the Census Bureau's disclosure rules. 
Panel A: Earnings Losses Using Matched Firms' Employees as Control Group

\begin{tabular}{|c|c|c|c|c|c|}
\hline "Dep. Var. = Log(Earnings) & (1) & (2) & (3) & (4) & (5) \\
\hline \multirow[t]{2}{*}{$\mathrm{d}[-3] \times \mathrm{BR}$} & -0.025 & -0.016 & -0.015 & -0.004 & -0.002 \\
\hline & $(-0.50)$ & $(-0.59)$ & $(-0.42)$ & $(-0.21)$ & $(-0.11)$ \\
\hline \multirow[t]{2}{*}{$d[-2] \times B R$} & -0.048 & -0.049 & -0.028 & -0.028 & 0.003 \\
\hline & $(-0.66)$ & $(-1.14)$ & $(-0.48)$ & $(-0.64)$ & $(0.05)$ \\
\hline \multirow[t]{2}{*}{$\mathrm{d}[-1] \times \mathrm{BR}$} & -0.013 & -0.044 & 0.007 & -0.016 & 0.023 \\
\hline & $(-0.15)$ & $(-1.00)$ & $(0.11)$ & $(-0.36)$ & $(0.36)$ \\
\hline \multirow[t]{2}{*}{$\mathrm{d}[0] \times \mathrm{BR}$} & -0.108 & $-0.103^{* * *}$ & $-0.087^{*}$ & $-0.097^{* * *}$ & $-0.073^{* * *}$ \\
\hline & $(-1.63)$ & $(-2.78)$ & $(-1.77)$ & $(-3.62)$ & $(-2.92)$ \\
\hline \multirow[t]{2}{*}{$\mathrm{d}[1] \times \mathrm{BR}$} & $-0.155^{* *}$ & $-0.129^{* * *}$ & $-0.091^{* *}$ & $-0.097^{* * *}$ & $-0.075^{* * *}$ \\
\hline & $(-2.42)$ & $(-4.17)$ & $(-2.02)$ & $(-4.11)$ & $(-3.82)$ \\
\hline \multirow[t]{2}{*}{$\mathrm{d}[2] \times \mathrm{BR}$} & $-0.192^{* * *}$ & $-0.150^{* * *}$ & $-0.114^{* *}$ & $-0.105^{* * *}$ & $-0.098^{* * *}$ \\
\hline & $(-2.69)$ & $(-4.38)$ & $(-2.39)$ & $(-3.66)$ & $(-3.73)$ \\
\hline \multirow[t]{2}{*}{$\mathrm{d}[3] \times \mathrm{BR}$} & $-0.125^{*}$ & $-0.104^{* * *}$ & $-0.099^{* *}$ & $-0.085^{* * *}$ & $-0.075^{* * *}$ \\
\hline & $(-1.74)$ & $(-3.08)$ & $(-1.97)$ & $(-2.68)$ & $(-2.59)$ \\
\hline \multirow[t]{2}{*}{$\mathrm{d}[4] \times \mathrm{BR}$} & $-0.172^{*}$ & $-0.129^{* * *}$ & $-0.115^{* *}$ & $-0.095^{* * *}$ & $-0.081^{* *}$ \\
\hline & $(-1.84)$ & $(-3.17)$ & $(-2.17)$ & $(-2.72)$ & $(-2.54)$ \\
\hline \multirow[t]{2}{*}{$\mathrm{d}[5] \times \mathrm{BR}$} & $-0.149^{*}$ & $-0.111^{* *}$ & $-0.103^{*}$ & $-0.072^{*}$ & $-0.065^{*}$ \\
\hline & $(-1.71)$ & $(-2.01)$ & $(-1.78)$ & $(-1.71)$ & $(-1.85)$ \\
\hline \multirow[t]{2}{*}{$\mathrm{d}[6] \times \mathrm{BR}$} & -0.149 & -0.092 & -0.098 & -0.053 & -0.057 \\
\hline & $-(1.46)$ & $(-1.60)$ & $(-1.55)$ & $(-1.17)$ & $(-1.51)$ \\
\hline \multirow{2}{*}{ Experience } & $-0.192^{* * *}$ & $-0.127^{* * *}$ & $-0.173^{* * *}$ & $-0.122^{* * *}$ & $-0.105^{* * *}$ \\
\hline & $-(11.14)$ & $(-13.79)$ & $(-12.83)$ & $(-13.50)$ & $(-11.96)$ \\
\hline \multirow[t]{2}{*}{ Female $\times$ Experience } & 0.006 & -0.003 & 0.002 & $-0.003^{* *}$ & $-0.004^{* * *}$ \\
\hline & (1.64) & $(-1.53)$ & $(0.86)$ & $(-1.97)$ & $(-2.64)$ \\
\hline \multirow[t]{2}{*}{ Experience $\times$ Education } & $-0.006^{* * *}$ & $-0.005^{* * *}$ & $-0.005^{* * *}$ & $-0.004^{* * *}$ & $-0.004^{* * *}$ \\
\hline & $(-17.08)$ & $(-24.50)$ & $(-22.93)$ & $(-22.32)$ & $(-19.43)$ \\
\hline $\begin{array}{l}\text { Standalone event year } \\
\text { indicators } \mathrm{d}[\mathrm{k}](-3 \leq k \leq 6)\end{array}$ & Yes & Yes & Yes & Yes & Yes \\
\hline Worker FE & Yes & Yes & Yes & Yes & Yes \\
\hline Year FE & Yes & & & & \\
\hline SIC2 $\times$ Year FE & & Yes & & Yes & \\
\hline County $\times$ Year FE & & & Yes & Yes & \\
\hline SIC2 $\times$ County $\times$ Year FE & & & & & Yes \\
\hline No. of worker-years & $4,672,000$ & $4,672,000$ & $4,672,000$ & $4,672,000$ & $4,672,000$ \\
\hline R-squared & $56.9 \%$ & $61.9 \%$ & $59.6 \%$ & $63.2 \%$ & $68.6 \%$ \\
\hline PV(Earnings losses) & $\begin{array}{l}-83.9 \%^{* *} \\
(-2.26)\end{array}$ & $\begin{array}{l}-67.1 \%{ }^{* * *} \\
(3.56)\end{array}$ & $\begin{array}{l}-57.9 \%^{* *} \\
(-2.27)\end{array}$ & $\begin{array}{c}-50.8 \%{ }^{* * * *} \\
(-3.08)\end{array}$ & $\begin{array}{l}-44.2 \%^{* * *} \\
(-3.04)\end{array}$ \\
\hline
\end{tabular}


Panel B: Earnings Losses Using Randomly Selected Workers as Control Group

\begin{tabular}{|c|c|c|c|c|c|}
\hline Dep. Var. = Log(Earnings) & (1) & $(2)$ & (3) & (4) & (5) \\
\hline \multirow[t]{2}{*}{$\mathrm{d}[-3] \times \mathrm{BR}$} & 0.022 & -0.006 & 0.013 & -0.002 & -0.001 \\
\hline & $(0.54)$ & $(-0.33)$ & $(0.38)$ & $(-0.14)$ & $(-0.08)$ \\
\hline \multirow[t]{2}{*}{$\mathrm{d}[-2] \times \mathrm{BR}$} & 0.022 & -0.010 & 0.025 & 0.006 & 0.020 \\
\hline & $(0.39)$ & $(-0.29)$ & $(0.48)$ & $(0.18)$ & $(0.43)$ \\
\hline \multirow[t]{2}{*}{$\mathrm{d}[-1] \times \mathrm{BR}$} & -0.035 & $-0.075^{*}$ & -0.018 & -0.048 & -0.026 \\
\hline & $(-0.57)$ & $(-1.90)$ & $(-0.34)$ & $(-1.18)$ & $(-0.58)$ \\
\hline \multirow[t]{2}{*}{$\mathrm{d}[0] \times \mathrm{BR}$} & $-0.121^{* *}$ & $-0.145^{* * *}$ & $-0.116^{* * *}$ & $-0.141^{* * *}$ & $-0.126^{* * *}$ \\
\hline & $(-2.40)$ & $(-4.82)$ & $(-2.78)$ & $(-5.15)$ & $(-5.28)$ \\
\hline \multirow[t]{2}{*}{$\mathrm{d}[1] \times \mathrm{BR}$} & $-0.175^{* * *}$ & $-0.167^{* * *}$ & $-0.150^{* * *}$ & $-0.156^{* * *}$ & $-0.122^{* * *}$ \\
\hline & $(-3.11)$ & $(-6.18)$ & $(-3.60)$ & $(-6.36)$ & $(-6.04)$ \\
\hline \multirow[t]{2}{*}{$\mathrm{d}[2] \times \mathrm{BR}$} & $-0.217^{* * *}$ & $-0.198^{* * *}$ & $-0.160^{* * * *}$ & $-0.154^{* * *}$ & $-0.117^{* * *}$ \\
\hline & $(-3.64)$ & $(-6.12)$ & $(-3.80)$ & $(-5.33)$ & $(-4.72)$ \\
\hline \multirow{2}{*}{$\mathrm{d}[3] \times \mathrm{BR}$} & $-0.156^{* * *}$ & $-0.124^{* * *}$ & $-0.110^{* *}$ & $-0.100^{* * *}$ & $-0.057^{* *}$ \\
\hline & $(-2.82)$ & $(-3.81)$ & $(-2.45)$ & $(-3.07)$ & $(-2.00)$ \\
\hline \multirow[t]{2}{*}{$\mathrm{d}[4] \times \mathrm{BR}$} & $-0.219^{* * *}$ & $-0.149^{* * *}$ & $-0.126^{* * *}$ & $-0.096^{* * *}$ & -0.038 \\
\hline & $(-2.86)$ & $(-3.92)$ & $(-2.97)$ & $(-2.94)$ & $(-1.30)$ \\
\hline \multirow[t]{2}{*}{$\mathrm{d}[5] \times \mathrm{BR}$} & $-0.155^{* *}$ & $-0.074^{*}$ & $-0.088^{*}$ & -0.035 & 0.016 \\
\hline & $(-2.30)$ & $(-1.83)$ & $(-1.77)$ & $(-0.92)$ & $(0.46)$ \\
\hline \multirow[t]{2}{*}{$\mathrm{d}[6] \times \mathrm{BR}$} & $-0.156^{*}$ & $-0.078^{*}$ & -0.079 & -0.031 & 0.020 \\
\hline & $(-1.80)$ & $(-1.82)$ & $(-1.50)$ & $(-0.90)$ & $(0.65)$ \\
\hline \multirow[t]{2}{*}{ Experience } & $-0.178^{* * *}$ & $-0.129^{* * *}$ & $-0.165^{* * *}$ & $-0.123^{* * *}$ & $-0.116^{* * *}$ \\
\hline & $(-16.92)$ & $(-17.59)$ & $(-17.29)$ & $(-17.29)$ & $(-15.71)$ \\
\hline \multirow[t]{2}{*}{ Female $\times$ Experience } & 0.004 & -0.002 & 0.003 & -0.002 & $-0.003^{* *}$ \\
\hline & $(1.48)$ & $(-1.27)$ & $(1.60)$ & $(-1.41)$ & $(-1.98)$ \\
\hline \multirow[t]{2}{*}{ Experience $\times$ Education } & $-0.005^{* * *}$ & $-0.004^{* * *}$ & $-0.005^{* * *}$ & $-0.004^{* * *}$ & $-0.004^{* * *}$ \\
\hline & $(-18.94)$ & $(-26.67)$ & $(-29.95)$ & $(-27.92)$ & $(-26.06)$ \\
\hline $\begin{array}{l}\text { Standalone event year } \\
\text { indicators } \mathrm{d}[\mathrm{k}](-3 \leq k \leq 6)\end{array}$ & Yes & Yes & Yes & Yes & Yes \\
\hline Worker FE & Yes & Yes & Yes & Yes & Yes \\
\hline Year FE & Yes & & & & \\
\hline SIC2 $\times$ Year FE & & Yes & & Yes & \\
\hline County $\times$ Year FE & & & Yes & Yes & \\
\hline SIC $2 \times$ County $\times$ Year FE & & & & & Yes \\
\hline No. of worker-years & $5,802,000$ & $5,802,000$ & $5,802,000$ & $5,802,000$ & $5,802,000$ \\
\hline R-squared & $58.7 \%$ & $62.0 \%$ & $60.2 \%$ & $63.0 \%$ & $67.9 \%$ \\
\hline PV(Earnings losses) & $\begin{array}{c}-94.8 \%{ }^{* * *} \\
(-3.21)\end{array}$ & $\begin{array}{c}-76.8 \%{ }^{* * *} \\
(-4.56)\end{array}$ & $\begin{array}{c}-68.5 \%^{* * *} \\
(-3.13)\end{array}$ & $\begin{array}{c}-60.3 \%{ }^{* * *} \\
(-3.80)\end{array}$ & $\begin{array}{c}-37.9 \%{ }^{* * *} \\
(-2.63)\end{array}$ \\
\hline
\end{tabular}


Panel C: Present Values of Earnings Losses after Imputing Missing Earnings in LEHD

\begin{tabular}{|c|c|c|c|c|c|}
\hline & (1) & $(2)$ & (3) & (4) & (5) \\
\hline & \multicolumn{5}{|c|}{$\begin{array}{l}\text { Imputing missing annual earnings with the employee's last } \\
\text { observed quarterly earnings } \times 4\end{array}$} \\
\hline \multirow[t]{2}{*}{ PV(Earnings losses) } & $\begin{array}{c}-71.1 \%{ }^{*} \\
(-1.72)\end{array}$ & $\begin{array}{c}-56.1 \% * * * \\
(-2.70)\end{array}$ & $\begin{array}{c}-53.7 \%{ }^{*} \\
(-1.80)\end{array}$ & $\begin{array}{c}-43.8 \%{ }^{* *} \\
(-2.37)\end{array}$ & $\begin{array}{c}-33.9 \%{ }^{*} \\
(-1.93)\end{array}$ \\
\hline & \multicolumn{5}{|c|}{$\begin{array}{l}\text { Imputing missing annual earnings with } 10^{\text {th }} \text { percentile of earnings } \\
\text { distribution of all employees in the sample }\end{array}$} \\
\hline PV(Earnings losses) & $\begin{array}{c}-67.5 \% \\
(-0.96)\end{array}$ & $\begin{array}{c}-115.7 \% \%^{* * *} \\
(3.80)\end{array}$ & $\begin{array}{c}-59.4 \% \\
(-1.44)\end{array}$ & $\begin{array}{c}-90.0 \%^{* * *} \\
(-3.91)\end{array}$ & $\begin{array}{c}-70.3 \%{ }^{* * *} \\
(-3.41)\end{array}$ \\
\hline Worker FE & Yes & Yes & Yes & Yes & Yes \\
\hline SIC2 $\times$ Year FE & Yes & Yes & Yes & Yes & Yes \\
\hline
\end{tabular}




\section{Table 5: Effect of Corporate Bankruptcy on Employee Earnings - Conditional Analysis on Worker Mobility, Labor Market Characteristics, and Bankruptcy Outcomes}

This table presents the present value of earnings losses conditional on worker mobility, labor market characteristics, and bankruptcy outcomes. "PV (Earnings losses)" is the present value of earnings losses from years $t$ to $t+6$ (computed using a real discount rate of $5.48 \%$ ) as a percent of the pre-bankruptcy annual earnings in t-4. Panel A reports the present values of earnings losses conditional on worker mobility. We define a worker as a stayer if she stays in the same firm, industry, or county through year $\mathrm{t}+3$ as her $\mathrm{t}-1$ firm, industry, or county. This panel stratifies the treated (i.e., bankrupt) firm employees based on whether they stay with their firms, industries, or counties, but not the control firm employees. Thus, the panel decomposes earnings losses of the treated group workers relative to the average worker in the control group. Panel B reports the present values of earnings losses conditional on firm size (measured by employment from the LBD), local labor market size (the number of workers in a given two-digit SIC industry and county cell), and bankruptcy outcomes (liquidation vs. non-liquidation). We split the sample at the third quartile of the firm size and labor market size distributions. This panel stratifies both the treated and control firm employees. $t$ statistics for the present value significantly differing from zero are in parentheses (standard errors are computed using the delta method). Statistical significance at the $10 \%, 5 \%$, and $1 \%$ levels is indicated by ${ }^{*},{ }^{* *}$, and ${ }^{* * *}$.

Panel A: Present Value of Earnings Losses Conditional on Worker Mobility

\begin{tabular}{lcccccc}
\hline \hline & $(1)$ & $(2)$ & $(3)$ & $(4)$ & $(5)$ & $(6)$ \\
Group & Firm & Firm & $\begin{array}{c}\text { Leavers: } \\
\text { same industry } \\
\text { same county }\end{array}$ & $\begin{array}{c}\text { Leavers: } \\
\text { diff. industry } \\
\text { same county }\end{array}$ & $\begin{array}{c}\text { Leavers: } \\
\text { same industry } \\
\text { diff. county }\end{array}$ & $\begin{array}{c}\text { Leavers: } \\
\text { diff. industry } \\
\text { diff. county }\end{array}$ \\
\hline PV(Earnings & $25.6 \%$ & $-85.9 \%^{* * *}$ & $-0.2 \%$ & $-11.5 \%$ & $69.8 \%^{* * *}$ & $-130.3 \%^{* * *}$ \\
losses) & $(0.96)$ & $(-4.63)$ & $(-0.01)$ & $(-0.53)$ & $(2.75)$ & $(-7.37)$ \\
\hline Controls & Yes & Yes & Yes & Yes & Yes & Yes \\
Worker FE & Yes & Yes & Yes & Yes & Yes & Yes \\
SIC2 $\times$ Year FE & Yes & Yes & Yes & Yes & Yes & Yes \\
\hline \hline
\end{tabular}

Panel B: Present Value of Earnings Losses Conditional on Firm Size, Local Market Size and Bankruptcy Outcome

\begin{tabular}{|c|c|c|c|c|c|c|c|c|}
\hline & (1) & (2) & (3) & (4) & (5) & (6) & (7) & (8) \\
\hline & \multicolumn{2}{|c|}{ Firm size } & \multicolumn{2}{|c|}{ Labor market size } & \multicolumn{4}{|c|}{ Bankruptcy outcome } \\
\hline & & & & & \multicolumn{2}{|c|}{ Liquidation } & \multicolumn{2}{|c|}{ Non-liquidation } \\
\hline & Large & Small & Large & Small & Large firm & Small firm & Large firm & Small firm \\
\hline $\begin{array}{l}\text { PV(Earnings } \\
\text { losses) }\end{array}$ & $\begin{array}{r}-15.6 \% \\
(-0.47)\end{array}$ & $\begin{array}{c}-79.1 \%{ }^{* * *} \\
(-4.07)\end{array}$ & $\begin{array}{c}-39.7 \%{ }^{*} \\
(-1.73)\end{array}$ & $\begin{array}{c}-79.0 \%{ }^{* * *} \\
(-4.15)\end{array}$ & $\begin{array}{c}-110.2 \%{ }^{* * *} \\
(-2.93)\end{array}$ & $\begin{array}{c}-150.2 \%{ }^{* * *} \\
(-7.28)\end{array}$ & $\begin{array}{l}-0.1 \% \\
(0.00)\end{array}$ & $\begin{array}{c}-72.0 \%{ }^{* * *} \\
(-3.31)\end{array}$ \\
\hline $\begin{array}{l}\text { Difference } \\
\text { between small } \\
\text { and large and its } \\
t \text {-statistic }\end{array}$ & \multicolumn{2}{|c|}{$\begin{array}{c}-63.5 \%{ }^{*} \\
(-1.85)\end{array}$} & \multicolumn{2}{|c|}{$\begin{array}{c}-39.3 \% \\
(-2.41)\end{array}$} & \multicolumn{2}{|c|}{$\begin{array}{c}-40.0 \% \\
(-0.93)\end{array}$} & \multicolumn{2}{|c|}{$\begin{array}{c}-71.9 \% \\
(-1.96)\end{array}$} \\
\hline Controls & Yes & Yes & Yes & Yes & Yes & Yes & Yes & Yes \\
\hline Worker FE & Yes & Yes & Yes & Yes & Yes & Yes & Yes & Yes \\
\hline SIC $2 \times$ Year FE & Yes & Yes & Yes & Yes & Yes & Yes & Yes & Yes \\
\hline
\end{tabular}




\section{Table 6: Effect of Corporate Bankruptcy on Employee Earnings - Financial Distress versus Economic Distress}

This table presents the present value of earnings losses conditional on bankrupt firms' financial and economic situations before bankruptcy. We split the bankrupt and matched firms in the full sample into four groups (high vs. low ROA and high vs. low leverage) at the medians of bankrupt firms' ROA and market leverage one year prior to bankruptcy filing (year t-1). For each group, we estimate the regression as in Table 4, Panel A, column (2). All regressions include control variables, worker fixed effects, and two-digit SIC industry $\times$ year fixed effects. We report the present values of earnings losses for each group from years $t$ to $t+6$ (computed using a real discount rate of 5.48\%) as a percent of the pre-bankruptcy annual earnings in t-4. $t$-statistics for the present value significantly differing from zero are in parentheses (standard errors are computed using the delta method). Statistical significance at the 10\%, 5\%, and $1 \%$ levels is indicated by ${ }^{*},{ }^{* *}$, and ${ }^{* * *}$.

\begin{tabular}{lcc}
\hline \hline PV (Earnings losses) & High leverage & Low leverage \\
\hline \multirow{3}{*}{ High ROA } & Group 1: & $\frac{\text { Group 2: }}{-33.7 \%}$ \\
& $-59.5 \%^{* * *}$ & $(-1.52)$ \\
\hline \multirow{3}{*}{ Low ROA } & $(-2.70)$ & $\underline{\text { Group 4: }}$ \\
& Group 3: & $-87.4 \%{ }^{* *}$ \\
\hline \hline
\end{tabular}




\section{Table 7: Leverage and Employee Wages - A Wage Regression Approach}

This table presents the relation between corporate leverage and employee earnings. The dependent variable is the log of employee annual earnings in 2001 constant dollars. Market leverage is defined as book value of total debt divided by the market value of assets. The control variables include log(book assets), market-to-book, ROA, asset tangibility of firms, gender, years of education, years of experience, gender $\times$ experience, gender $\times$ education, experience $\times$ education of individual workers, and county $\times$ two-digit SIC industry $\times$ year fixed effects. To select the sample for the regression, we begin with Compustat firms with S\&P credit ratings between 'AA+' and 'B-' and book assets greater than $\$ 100$ million in 1980 constant dollars and less than or equal to the assets of the largest firm in our bankrupt firm sample from 1986 to 2008. Then we select a 10\% random sample of all worker-years in LEHD with ages between 22 and 50 and at least two years of tenure in these firms. Column (1) presents estimates for the full sample. Column (2) presents estimates conditional on firm employment size, measured by the number of employees in a given firm. Column (3) presents estimates conditional on local labor market size, measured by the number of workers in a given two-digit SIC industry and county cell. "Large” ("Small”) is an indicator variable equal to one if firm employment or local labor market size is greater than (less than or equal to) the third quartile in the sample distribution. Definitions of variables are in the Appendix. Heteroskedasticity robust $t$-statistics adjusted for within-firm clustering are in parentheses. Statistical significance at the $10 \%, 5 \%$, and $1 \%$ levels is indicated by ${ }^{*}{ }^{* *}$, and ${ }^{* * *}$. The number of observations is rounded to the nearest thousands to follow the Census Bureau's disclosure rules.

\begin{tabular}{lccc}
\hline \hline Dep. Var. = Log(Earnings) & Full & Firm employment size & Labor market size \\
\hline & $(1)$ & $(2)$ & $(3)$ \\
\cline { 2 - 4 } Market leverage & $0.171^{*}$ & & \\
& $(1.66)$ & & 0.060 \\
Market leverage $\times$ Large & & -0.089 & $(0.50)$ \\
& & $-(0.63)$ & $0.253^{* *}$ \\
Market leverage $\times$ Small & & $0.208^{*}$ & $(2.25)$ \\
& Yes & $(1.82)$ & Yes \\
Controls & Yes & Yes & Yes \\
County $\times$ SIC2 $\times$ Year FE & $32.5 \%$ & Yes & $32.5 \%$ \\
R-squared & $2,699,000$ & $32.5 \%$ & $2,699,000$ \\
No. of worker-years & & $2,699,000$ & \\
\hline \hline
\end{tabular}




\section{Table 8: Implied Annual Wage Premia}

This table develops implied annual wage premia for firms with different credit ratings. We use the PV of earnings losses as a fraction of pre-bankruptcy annual wages in a binomial valuation model (see Section A.1 of the online appendix) to derive the implied wage premia. We first calculate a one-year risk-adjusted bankruptcy probability q in column (2) as $1-\left(1-0.6 \times \mathrm{p}_{10}\right)^{1 / 10}$, where 0.6 is the estimated probability of bankruptcy conditional on default (based on Moody's Default and Recovery Database and the Altman-Kuehne/NYU Salomon Center Bond Master Default Database), and $\mathrm{p}_{10}$ (in column (1)) is the ten-year risk-adjusted default probability provided in Almeida and Philippon (2007, Table III). In column (3), we use this annual q to calculate the PV wage premium a firm would pay workers per year as $\left[\mathrm{q} \times(\mathrm{L} / \mathrm{W}) /\left(1+\mathrm{r}_{\mathrm{f}}\right)\right]$, where "L" represents the present value of earnings loss given bankruptcy and "W" represents pre-bankruptcy annual wages. The risk-free rate $\left(\mathrm{r}_{\mathrm{f}}\right)$ is assumed to be $5.61 \%$, the average 10 -year Treasury rate from 1985-2008, our sample period. All numbers in the table are in \%.

\begin{tabular}{|c|c|c|c|}
\hline Credit rating & $\begin{array}{c}\mathrm{p}_{10}=\text { Ten-year risk- } \\
\text { adjusted default } \\
\text { probability from Almeida } \\
\text { and Philippon (2007) } \\
\text { (1) }\end{array}$ & $\begin{array}{l}\mathrm{q}=\text { One-year risk- } \\
\text { adjusted bankruptcy } \\
\text { probability } \\
\text { (2) }\end{array}$ & $\begin{array}{c}\text { Implied annual wage } \\
\text { premium as a fraction of } \\
\text { wages } \\
\text { (Binomial valuation model) } \\
\text { (3) }\end{array}$ \\
\hline AAA & 1.65 & 0.10 & 0.06 \\
\hline AA & 6.75 & 0.41 & 0.26 \\
\hline $\mathrm{A}$ & 12.72 & 0.79 & 0.50 \\
\hline $\mathrm{BBB}$ & 20.88 & 1.33 & 0.84 \\
\hline BB & 39.16 & 2.64 & 1.68 \\
\hline $\mathrm{B}$ & 62.48 & 4.59 & 2.92 \\
\hline BBB minus AA & 14.13 & 0.92 & 0.58 \\
\hline
\end{tabular}




\section{Table 9: Comparison of Annual Wage Premia as a Fraction of Wages - Binomial Valuation Model versus Wage Regression Approaches}

This table compares the implied annual wage premia derived from the binomial valuation model in Table 8 with those estimated from the wage regression in Table 7. In particular, it presents the additional wage premium due to moving from AA to BBB ratings. Column (1) presents the results for the full sample, and columns (2) through (5) present for subsamples by firm employment size and labor market size. Firm employment size is measured by the number of employees in a given firm, and local labor market size is by the number of workers in a given two-digit SIC industry and county cell. "Large" ("Small”) represents a subsample in which firm employment or local labor market size is greater than (less than or equal to) the third quartile in the sample distribution. Panel A (B) presents the change in implied annual wage premia estimated from the binomial valuation model (wage regression in Table 7) as a percent of the firm's wage bill. Statistical significance, based on estimates from Tables 4 and 5 (for the valuation model) and Table 7 (for wage regressions), at the $10 \%, 5 \%$, and $1 \%$ levels is indicated by ${ }^{*},{ }^{* *}$, and ${ }^{* * *}$.

\begin{tabular}{cccccc}
\hline \hline & Full & \multicolumn{2}{c}{ Firm employment size } & \multicolumn{2}{c}{ Labor market size } \\
\cline { 3 - 6 } & $\begin{array}{c}\text { Sample } \\
(1)\end{array}$ & $\begin{array}{c}\text { Large } \\
(2)\end{array}$ & $\begin{array}{c}\text { Small } \\
(3)\end{array}$ & $\begin{array}{c}\text { Large } \\
(4)\end{array}$ & $\begin{array}{c}\text { Small } \\
(5)\end{array}$ \\
\hline \multicolumn{7}{c}{ Panel A: Binomial Valuation Model } \\
\hline $\begin{array}{c}\text { PV (wage premia) } \\
\text { BBB minus AA }\end{array}$ & $0.58 \%{ }^{* * *}$ & $0.14 \%$ & $0.69 \%^{* * *}$ & $0.34 \%^{*}$ & $0.69 \%{ }^{* * *}$ \\
\hline $\begin{array}{c}\text { PV (wage premia) } \\
\text { BBB minus AA }\end{array}$ & Panel B: Wage Regression & & \\
\hline \hline
\end{tabular}




\section{Table 10: Capitalized Value of Implied Wage Premia, Tax Benefits of Financial Leverage and Expected Costs of Financial}

Distress

This table develops the capitalized value of implied wage premia as a fraction of firm value for firms with different credit ratings, and compares them with the tax benefits of debt and expected costs of financial distress. Column (1) presents the annual wage premium as a fraction of firm value. Column (2) calculates the PV of implied wage premia as a fraction of firm value that the firm would pay workers in an infinite horizon (i.e., capitalized value) as $\left[\mathrm{q} /\left(\mathrm{q}+\mathrm{r}_{\mathrm{f}}\right)\right] \times \mathrm{L} / \mathrm{MV}$, where " $\mathrm{L}$ " represents the present value of earnings loss given bankruptcy and "MV" represents firm value. The risk-free rate ( $\mathrm{r}_{\mathrm{f}}$ ) is assumed to be $5.61 \%$, the average 10 -year Treasury rate from 1985-2008, our sample period. The online appendix provides detailed models underlying these wage premia calculations. Columns (3)-(5) show the tax benefits of debt and expected costs of financial distress estimated from Almeida and Philippon (2007, Table VI) and Elkamhi, Ericsson, and Parsons (2012, Tables 2 and 3). Wage premia, tax benefits and expected costs of financial distress in the table are present values as percentages of pre-bankruptcy firm value.

\begin{tabular}{|c|c|c|c|c|c|}
\hline Credit rating & $\begin{array}{l}\text { Implied annual } \\
\text { wage premium as } \\
\text { fraction of firm } \\
\text { value } \\
\text { (1) }\end{array}$ & $\begin{array}{l}\text { Capitalized value of } \\
\text { implied wage premium as } \\
\text { fraction of firm value } \\
\text { (2) }\end{array}$ & $\begin{array}{l}\text { Tax benefits of } \\
\text { debt from } \\
\text { Almeida and } \\
\text { Philippon (2007) } \\
\text { (3) }\end{array}$ & $\begin{array}{c}\text { E(costs of } \\
\text { financial distress) } \\
\text { from Almeida and } \\
\text { Philippon (2007) } \\
\text { (4) }\end{array}$ & $\begin{array}{l}\text { E(costs of financial } \\
\text { distress) from } \\
\text { Elkamhi, Ericsson, } \\
\text { Parsons (2012) } \\
\text { (5) }\end{array}$ \\
\hline AAA & 0.02 & 0.33 & 0.47 & 0.32 & 0.0 \\
\hline AA & 0.07 & 1.29 & 2.51 & 1.84 & 0.0 \\
\hline A & 0.14 & 2.33 & 4.40 & 3.84 & 0.2 \\
\hline $\mathrm{BBB}$ & 0.24 & 3.61 & 5.18 & 4.53 & 0.5 \\
\hline $\mathrm{BB}$ & 0.47 & 6.03 & 7.22 & 6.81 & 0.9 \\
\hline B & 0.82 & 8.47 & 8.95 & 9.54 & 2.1 \\
\hline BBB minus AA & 0.17 & 2.32 & 2.67 & 2.69 & 0.5 \\
\hline
\end{tabular}




\title{
Employee Costs of Corporate Bankruptcy Online Appendix ${ }^{*}$
}

\author{
John R. Graham \\ Hyunseob Kim \\ $\mathrm{Si} \mathrm{Li}$ \\ Jiaping Qiu ${ }^{\dagger}$
}

May 2019

Abstract
This online appendix presents a detailed model to compute wage premia and supplementary tables.

\footnotetext{
* Any opinions and conclusions expressed herein are those of the author and do not necessarily represent the views of the U.S. Census Bureau. All results have been reviewed to ensure that no confidential information is disclosed. This research uses data from the Census Bureau's Longitudinal Employer Household Dynamics Program, which was partially supported by the following National Science Foundation Grants SES-9978093, SES-0339191 and ITR0427889; National Institute on Aging Grant AG018854; and grants from the Alfred P. Sloan Foundation.

† John R. Graham (john.graham@duke.edu), Fuqua School of Business, Duke University, Durham NC 27708, phone: (919) 660-7857; Hyunseob Kim (hk722@cornell.edu), Samuel Curtis Johnson Graduate School of Management, Cornell University, Ithaca, NY 14583, phone: (607) 255-8335; Si Li (sli@wlu.ca), Financial Services Research Centre, Lazaridis School of Business and Economics, Wilfrid Laurier University, Waterloo, Ontario N2L 3C5, Canada, phone: (519) 884-0710 ext. 2395; Jiaping Qiu (qiu@mcmaster.ca), DeGroote School of Business, McMaster University, Hamilton, Ontario L8S 4M4, Canada, phone: (905) 525-9140 ext. 23963.
} 


\section{Online Appendix: Binomial Valuation Model to Compute Implied Wage Premia Due to Bankruptcy Risk}

In a competitive labor market, when an employee expects earnings reductions following a bankruptcy filing of her employer, she will require higher wages ex ante to compensate for such a potential loss. In this appendix, we first derive annual wage premium demanded by an employee in Section A.1 and then the capitalized value of wage premium paid by a firm with an infinite life (going concern) in Section A.2.

\section{A.1. Annual Wage Premium the Firm Pays a Worker}

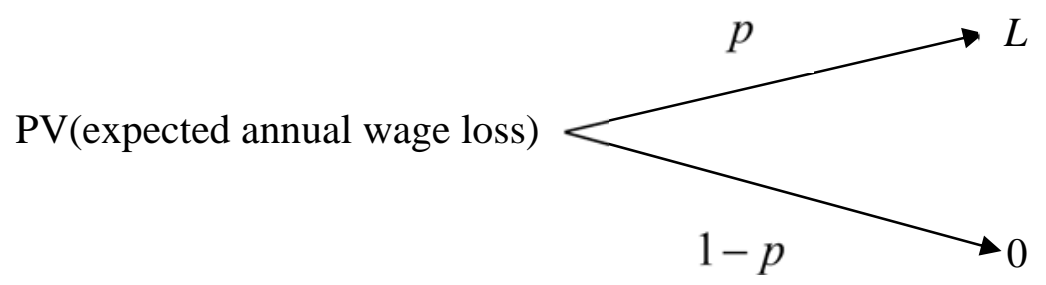

Figure A.1

Let $L$ be the employee’s earnings losses given bankruptcy of her employer, $p$ the historical annual probability of bankruptcy, and $r_{D}$ the appropriate discount rate. Note that $L$ could be normalized by wage or firm value as in the paper. Then the present value of expected earnings losses in a given year is equal to:

$$
P V(\text { expected annual wage loss })=\frac{p L}{1+r_{D}} \text {. }
$$

Assuming that the employee is risk averse and that the firm is more likely to file for bankruptcy in bad times, the discount rate $r_{D}<r_{f}$, the risk-free rate. Because we do not observe $r_{D}$, we adopt a risk-neutral approach proposed in Almeida and Philippon (2007) to estimate the PV expected annual wage loss. Specifically, 


$$
P V(\text { expected annual wage loss })=\frac{q L}{1+r_{f}}
$$

where $q$ is the annual risk-adjusted probability of bankruptcy and $r_{f}$ is the risk-free rate.

If we use a risk-free firm (i.e., $q=0$ ) as the benchmark case, in a competitive labor market the risky firm has to offer the same expected annual wages, $W_{1}-P V($ expected annual wage loss), to the employee as the wages offered by a risk-free firm $W_{0}$, other things held constant. This implies that the annual wage premium demanded by the employee over a risk-free firm is:

$$
\begin{aligned}
\text { annual wage premium } & =W_{1}-W_{0} \\
& =P V(\text { expected annual wage loss })=\frac{q L}{1+r_{f}} .
\end{aligned}
$$

This result is intuitive: the annual wage premium is equal to the marginal increase in the PV expected annual earnings loss resulting from a marginal increase in annual bankruptcy probability.

\section{A.2. Capitalized Value of Wage Premium the Firm Pays a Worker}

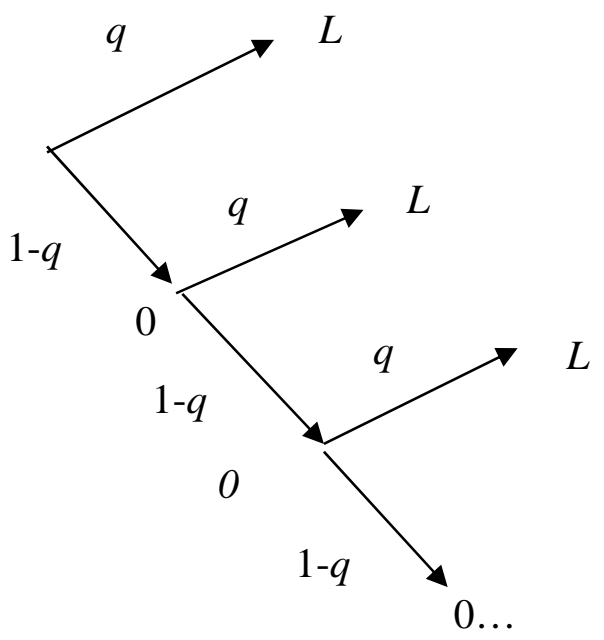

Figure A.2

In an infinite-period model, the firm will have an employee indefinitely. If we use a risk-free firm as the benchmark, in year 0, the employee faces a risk-adjusted bankruptcy probability $q$ and 
the firm will need to offer an annual wage premium of $\frac{q L}{1+r_{f}}$ over a risk-free firm as shown in equation (A-3). If the firm survives to the next year (with probability $1-q$ ), the employee again will face a risk-adjusted bankruptcy probability $q$ in that year, and the firm will again pay an annual wage premium of $\frac{q L}{1+r_{f}}$ over a risk-free firm. ${ }^{3}$ Continuing this process indefinitely, the PV of wage premium that the firm has to offer over a risk free firm over its life is:

$$
P V \text { of wage premium }=\sum_{t=0}^{\infty} \text { annual wage premium } \times\left(\frac{1-q}{1+r_{f}}\right)^{t} .
$$

Using a perpetuity formula, equation (A-4) can be re-written as:

$$
\text { PV of wage premium }
$$

$$
\begin{aligned}
& =\text { Annual wage premium }+ \text { annual wage premium } \times \frac{1-q}{r_{f}+q} \\
& =\frac{q L}{1+r_{f}} \times\left(1+\frac{1-q}{r_{f}+q}\right)=\frac{q L}{r_{f}+q} .
\end{aligned}
$$

In general, the difference in the capitalized value of wage premium between any two firms with risk-adjusted bankruptcy probabilities $q_{2}$ and $q_{1}\left(q_{2}>q_{1}\right)$ is equal to:

$$
\text { Difference in PV of wage premium }=\frac{q_{2} L}{r_{f}+q_{2}}-\frac{q_{1} L}{r_{f}+q_{1}} \text {. }
$$

For example, if a firm's credit rating changes from AA to BBB, the capitalized value of wage premium of AA over BBB is equal to $\frac{q_{B B B} L}{r_{f}+q_{B B B}}-\frac{q_{A A} L}{r_{f}+q_{A A}}$.

\footnotetext{
${ }^{3}$ Note that this model does not require that the same employees work for the firm indefinitely. Workers receive a risk premium to compensate them for the risk that the firm might go bankrupt in the current period. If the firm survives the next period, it will compensate its workers for the risk of bankruptcy in that period, whether they are the same employees that worked in the previous period or not.
} 


\section{A.3. Capitalized Value of Wage Premium, Adjusting for Pre-bankruptcy Wage Premium}

Section A.1 shows that the annual wage premium for bankruptcy risk is $\frac{q L}{1+r_{f}}$. If normalized by wages, the annual wage premium as a fraction of wages is $\frac{q\left(\frac{L}{W}\right)}{1+r_{f}}$, where $r_{f}$ is the risk-free rate, $q$ is the annual risk-adjusted (i.e., risk-neutral) bankruptcy probability, and $L / W$ is the present value of employee earnings losses given bankruptcy as a fraction of pre-bankruptcy wages (i.e., $67.1 \%$ as in Table 4, Panel A, column (2)). Part of the present value of earnings loss $L / W$ might be due to the loss of a compensation differential that existed pre-bankruptcy, which we attempt to tease out as follows.

We first take the coefficient on market leverage of 0.171 in column (1) of Table 7 as "causal," which suggests that a one-percentage-point increase in leverage is associated with a $0.186 \%(=\exp (0.171)-1)$ increase in annual earnings (although we fully acknowledge that this estimate is likely affected by omitted variables, among other things). We then multiply the $0.186 \%$ by the difference in market leverage between the bankrupt and matched firms in t- 4 (which is $13.6 \%$ $=34.3 \%-20.8 \%$ ) to get an estimated annual wage premium of bankrupt firms over matched firms that existed pre-bankruptcy, which equals $2.5 \%(=0.186 \% \times 13.6 \%)$. This estimate implies that the loss of the pre-bankruptcy annual wage premium may contribute a $2.5 \%$ earnings loss (out of about an $11 \%$ loss on average) in each year from $t$ to $t+6$. The present value of the loss of this prebankruptcy wage premium from year $t$ to $t+6$ is equal to $2.5 \%$ times the present value factor for seven years (5.66), which is $14.4 \%(=2.5 \% \times 5.66)$.

Next, we subtract this present value of the lost pre-bankruptcy wage premium (14.4\%) from the present value of employee earnings losses given bankruptcy $(L / W=67.1 \%)$ to obtain an adjusted present value of employee earnings losses (“adjusted $L / W$ ”), which is $52.7 \%$ (= 67.1\% - 
14.4\%). Lastly, with the adjusted L/W, we re-calculate the capitalized value of wage premium as a fraction of firm value for firms with different credit ratings following the same procedure described in Section 4.4 of the paper. Online Appendix Table A5 shows that the adjustment leads to a smaller PV of implied wage premia.

\section{Reference:}

Almeida, Heitor and Thomas Philippon, 2007, The Risk-Adjusted Cost of Financial Distress, Journal of Finance 62, 2557-2586. 


\section{Online Appendix Table A1: Effect of Bankruptcy on Employee Earnings When Control Group is Matched Using Observations from the Baseline Year, t-4}

This table presents the present value of earnings losses by constructing matched firms based on the information in the baseline year, t-4. "PV (Earnings losses)" is the present value of earnings losses from years t to $t+6$ (computed using a real discount rate of 5.48\%) as a percent of the pre-bankruptcy annual earnings in t-4. Heteroskedasticity robust $t$ statistics adjusted for within-firm clustering are in parentheses (standard errors are computed using the delta method). Statistical significance at the $10 \%, 5 \%$, and $1 \%$ levels is indicated by ${ }^{*},{ }^{* *}$, and ${ }^{* * *}$, respectively. The number of observations is rounded to the nearest thousands to follow the Census Bureau's disclosure rules.

\begin{tabular}{|c|c|c|c|c|c|}
\hline & $(1)$ & $(2)$ & (3) & $(4)$ & $(5)$ \\
\hline Control variables & Yes & Yes & Yes & Yes & Yes \\
\hline Worker FE & Yes & Yes & Yes & Yes & Yes \\
\hline Year FE & Yes & & & & \\
\hline SIC2 $\times$ Year FE & & Yes & & Yes & \\
\hline County $\times$ Year FE & & & Yes & Yes & \\
\hline SIC $2 \times$ County $\times$ Year FE & & & & & Yes \\
\hline No. of worker-years & $2,002,000$ & $2,002,000$ & $2,002,000$ & $2,002,000$ & $2,002,000$ \\
\hline $\begin{array}{l}\text { PV(Earnings losses) } \\
\text { as \% of pre-bankruptcy } \\
\text { annual earnings }\end{array}$ & $\begin{array}{l}-57.1 \% \\
(-0.95)\end{array}$ & $\begin{array}{c}-58.9 \%{ }^{* * *} \\
(-2.82)\end{array}$ & $\begin{array}{l}-84.2 \% \\
(-1.45)\end{array}$ & $\begin{array}{c}-55.5 \%{ }^{* *} \\
(-2.47)\end{array}$ & $\begin{array}{c}-67.4 \%{ }^{* * *} \\
(-2.62)\end{array}$ \\
\hline
\end{tabular}




\section{Online Appendix Table A2: Effect of Corporate Bankruptcy on Employee Earnings After Imputing Missing Earnings}

This table presents the present value of earnings losses using the matched firms' employees as the control group and after imputing missing earnings in LEHD. "PV (Earnings losses)" is the present value of earnings losses from years t to $t+6$ (computed using a real discount rate of 5.48\%) as a percent of the pre-bankruptcy annual earnings in t-4. Column (1) shows the baseline PV estimates from Table 4, Panel A, column (2). Columns (2) and (3) impute missing earnings in LEHD with the last observed quarterly earnings times four and the $10^{\text {th }}$ percentile value of the earnings distribution in our sample. Column (4) imputes missing earnings in LEHD with the $10^{\text {th }}$ percentile value of the earnings distribution in our sample for a subset of employees who are originally employed in states whose all neighboring states are in LEHD. Heteroskedasticity robust $t$-statistics adjusted for within-firm clustering are in parentheses (standard errors are computed using the delta method). Statistical significance at the $10 \%, 5 \%$, and $1 \%$ levels is indicated by ${ }^{*},{ }^{* *}$, and ${ }^{* * *}$, respectively.

\begin{tabular}{lcccc}
\hline \hline & $(1)$ & $(2)$ & $(3)$ & $(4)$ \\
\hline & Baseline & $\begin{array}{c}\text { Impute with last } \\
\text { observed quarterly } \\
\text { earnings } \times 4\end{array}$ & $\begin{array}{c}\text { Impute with } 10^{\text {th }} \\
\text { percentile earnings }\end{array}$ & $\begin{array}{c}\text { Impute with } 10^{\text {th }} \\
\text { percentile earnings } \\
\text { (neighboring states) }\end{array}$ \\
\hline Control variables & Yes & Yes & Yes & Yes \\
Worker FE & Yes & Yes & Yes & Yes \\
SIC2 $\times$ Year FE & Yes & Yes & Yes & Yes \\
PV(Earnings losses) & $-67.1 \%^{* * *}$ & $-56.1 \% \%^{* * *}$ & $-115.7 \%^{* * *}$ & $-74.2 \%{ }^{* *}$ \\
\hline \hline
\end{tabular}




\section{Online Appendix Table A3: Alternative Definition of Firm, Industry, and County Stayers in Year $t+3$ vs. $t+5$}

This table presents the present value of earnings losses conditional on mobility of employees of the bankrupt firms. "PV (Earnings losses)" is the present value of earnings losses from years t to $t+6$ (computed using a real discount rate of 5.48\%) as a percent of the pre-bankruptcy annual earnings in t-4. Panel A (Panel B) defines a worker as a stayer if she stays in the same firm, industry, or county through year $t+3(t+5)$ as her $t-1$ firm, industry, or county. Heteroskedasticity robust $t$-statistics adjusted for within-firm clustering are in parentheses (standard errors are computed using the delta method). Statistical significance at the $10 \%, 5 \%$, and $1 \%$ levels is indicated by ${ }^{*}{ }^{* *}$, and ${ }^{* * *}$, respectively.

\begin{tabular}{|c|c|c|c|c|c|c|}
\hline & $(1)$ & $(2)$ & $(3)$ & $(4)$ & $(5)$ & $(6)$ \\
\hline Group & Firm stayers & Firm leavers & $\begin{array}{c}\text { Leavers: } \\
\text { same industry } \\
\text { same county }\end{array}$ & $\begin{array}{c}\text { Leavers: } \\
\text { diff. industry } \\
\text { same county }\end{array}$ & $\begin{array}{c}\text { Leavers: } \\
\text { same industry } \\
\text { diff. county }\end{array}$ & $\begin{array}{c}\text { Leavers: } \\
\text { diff. industry } \\
\text { diff. county }\end{array}$ \\
\hline \multicolumn{7}{|c|}{ Panel A: Stayers Defined in $t+3$} \\
\hline $\begin{array}{l}\text { PV(Earnings } \\
\text { losses) }\end{array}$ & $\begin{array}{l}25.6 \% \\
(0.96)\end{array}$ & $\begin{array}{c}-85.9 \%{ }^{* * *} \\
(-4.63)\end{array}$ & $\begin{array}{l}-0.2 \% \\
(-0.01)\end{array}$ & $\begin{array}{l}-11.5 \% \\
(-0.53)\end{array}$ & $\begin{array}{c}69.8 \%{ }^{* * *} \\
(2.75)\end{array}$ & $\begin{array}{c}-130.3 \%{ }^{* * *} \\
(-7.37)\end{array}$ \\
\hline \multicolumn{7}{|c|}{ Panel B: Stayers Defined in $t+5$} \\
\hline $\begin{array}{l}\text { PV(Earnings } \\
\text { losses) }\end{array}$ & $\begin{array}{c}54.5 \%{ }^{* *} \\
(1.96)\end{array}$ & $\begin{array}{c}-78.4 \%^{* * *} \\
(-4.28)\end{array}$ & $\begin{array}{c}40.4 \%{ }^{*} \\
(1.69)\end{array}$ & $\begin{array}{l}-12.0 \% \\
(-0.63)\end{array}$ & $\begin{array}{c}54.8 \%{ }^{* *} \\
(2.53)\end{array}$ & $\begin{array}{c}-129.0 \%{ }^{* * *} \\
(-8.48)\end{array}$ \\
\hline Controls & Yes & Yes & Yes & Yes & Yes & Yes \\
\hline Worker FE & Yes & Yes & Yes & Yes & Yes & Yes \\
\hline SIC2 $\times$ Year FE & Yes & Yes & Yes & Yes & Yes & Yes \\
\hline
\end{tabular}




\section{Online Appendix Table A4: Present Value of Earnings Losses Conditional on Firm, Industry, and County Stayer Status of both Treated and Control Groups}

This table presents the present value of earnings losses conditional on mobility of employees of both bankrupt and matched control firms. The main difference between this table and Table 5, Panel A in the main text is as follows. This table stratifies both the treated (i.e., bankrupt) and control firm employees. Thus, this table examines how stayers (leavers) of the bankrupt firm fare relative to the stayers (leavers) of the control firm. In contrast, Table 5, Panel A stratifies the treated firm employees based on whether they stay with their firms, industries, or counties, but not the control firm employees. Thus, the panel decomposes earnings losses of the treated group relative to the average worker in the control group. "PV (Earnings losses)" is the present value of earnings losses from years $t$ to $t+6$ (computed using a real discount rate of 5.48\%) as a percent of the pre-bankruptcy annual earnings in t-4. We define a worker as a stayer if she stays in the same firm, industry, or county through year t+3 as her t- 1 firm, industry, or county. Heteroskedasticity robust $t$-statistics adjusted for within-firm clustering are in parentheses (standard errors are computed using the delta method). Statistical significance at the $10 \%, 5 \%$, and $1 \%$ levels is indicated by ${ }^{*},{ }^{* *}$, and ${ }^{* * *}$, respectively.

\begin{tabular}{|c|c|c|c|c|c|c|}
\hline & $(1)$ & $(2)$ & (3) & (4) & (5) & $(6)$ \\
\hline Group & Firm stayers & Firm leavers & $\begin{array}{c}\text { Leavers: } \\
\text { same industry } \\
\text { same county }\end{array}$ & $\begin{array}{c}\text { Leavers: } \\
\text { diff. industry } \\
\text { same county }\end{array}$ & $\begin{array}{c}\text { Leavers: } \\
\text { same industry } \\
\text { diff. county }\end{array}$ & $\begin{array}{c}\text { Leavers: } \\
\text { diff. industry } \\
\text { diff. county }\end{array}$ \\
\hline $\begin{array}{l}\text { PV(Earnings } \\
\text { losses) } \\
\text { as \% of pre- } \\
\text { bankruptcy } \\
\text { annual earnings }\end{array}$ & $\begin{array}{c}-71.8 \%{ }^{* *} \\
(-2.42)\end{array}$ & $\begin{array}{c}-54.9 \%{ }^{* * *} \\
(-3.13)\end{array}$ & $\begin{array}{c}-98.5 \%{ }^{* * *} \\
(-4.11)\end{array}$ & $\begin{array}{c}-38.5 \%{ }^{*} \\
(-1.95)\end{array}$ & $\begin{array}{l}-8.0 \% \\
(-0.37)\end{array}$ & $\begin{array}{c}-58.5 \%{ }^{* * *} \\
(-3.39)\end{array}$ \\
\hline Controls & Yes & Yes & Yes & Yes & Yes & Yes \\
\hline Worker FE & Yes & Yes & Yes & Yes & Yes & Yes \\
\hline SIC2 $\times$ Year FE & Yes & Yes & Yes & Yes & Yes & Yes \\
\hline
\end{tabular}




\section{Online Appendix Table A5: Capitalized Value of Implied Wage Premia with and without Adjustment for Pre-Bankruptcy Wage Premium}

This table compares the capitalized value of implied wage premia as a fraction of firm value, with (column (1)) and without (column (2)) adjustment for pre-bankruptcy wage premium.

\begin{tabular}{ccc}
\hline \hline & \multicolumn{2}{c}{ Capitalized value of implied wage } \\
& $(1)$ & $\begin{array}{c}(2) \\
\text { premium as fraction of firm value (Binomial valuation model) }\end{array}$ \\
\hline Credit rating & With adjustment & $\begin{array}{c}\text { Without adjustment } \\
\text { (Table 10, column (2)) }\end{array}$ \\
\hline AAA & 0.26 & 0.33 \\
AA & 1.01 & 1.29 \\
A & 1.83 & 2.33 \\
BBB & 2.84 & 3.61 \\
BB & 4.74 & 6.03 \\
B & 6.67 & 8.40 \\
\hline BBB minus AA & 1.82 & 2.32 \\
\hline \hline
\end{tabular}

